NBER WORKING PAPER SERIES

\title{
CAN SUPERSTITION CREATE A SELF-FULFILLING PROPHECY? SCHOOL OUTCOMES OF DRAGON CHILDREN OF CHINA
}

\author{
Naci H. Mocan \\ Han $\mathrm{Yu}$ \\ Working Paper 23709 \\ http://www.nber.org/papers/w23709 \\ NATIONAL BUREAU OF ECONOMIC RESEARCH \\ 1050 Massachusetts Avenue \\ Cambridge, MA 02138 \\ August 2017, Revised May 2019
}

We thank Paola Giuliano, Nathan Nunn, Leyla Mocan, Hanming Fang, Uta Schoenberg, Jeanet Bentzen, Anastasia Litina and Andreas Irmen for helpful suggestions. Seminar participants of the Study of the Religion, Economics and Culture Workshop at Chapman University, Southern Economic Association Conference in Washington D.C., and the 2018 ASREC Europe Conference in Luxembourg City provided useful comments. The views expressed herein are those of the authors and do not necessarily reflect the views of the National Bureau of Economic Research.

NBER working papers are circulated for discussion and comment purposes. They have not been peer-reviewed or been subject to the review by the NBER Board of Directors that accompanies official NBER publications.

(C) 2017 by Naci H. Mocan and Han Yu. All rights reserved. Short sections of text, not to exceed two paragraphs, may be quoted without explicit permission provided that full credit, including () notice, is given to the source. 
Can Superstition Create a Self-Fulfilling Prophecy? School Outcomes of Dragon Children of China

Naci H. Mocan and Han Yu

NBER Working Paper No. 23709

August 2017, Revised May 2019

JEL No. D91,I21,Z1

\begin{abstract}
In Chinese culture those who are born in the year of the Dragon under the zodiac calendar are believed to be destined for good fortune and greatness, and parents prefer their kids to be born in a Dragon year. Using provincial level panel data, we first show that the number of marriages goes up during the two years preceding a Dragon year and that births jump up in a Dragon year. Using three recently collected micro data sets from China we show that those born in a Dragon year are more likely to have a college education, and that they obtain higher scores at the university entrance exam. Similarly, Chinese middle school students have higher test scores if they are born in a Dragon year. We show that these results are not because of family background, student selfesteem or students' expectations about their future. We find, however, that the "Dragon" effect on test scores is eliminated when we account for parents' expectations about their children's educational and professional success. We find that parents of Dragon children have higher expectations for their children in comparison to other parents, and that they invest more heavily in their children in terms of time and money. We also show that girls are about six cm shorter than boys, but that this height disadvantage is cut by about half if a girl is born in the year of the Dragon and that effect is twice as strong in rural areas. Given that childhood nutrition is related to adolescent height, this suggests that parents may also be investing in Dragon girls in terms of nutrition. The results are insensitive to model specification and estimation strategy, including using an RD design. These results show that even though neither the Dragon children nor their families are inherently different from other children and families, the belief in the prophecy of success and the ensuing investment become self-fulfilling.
\end{abstract}

Naci H. Mocan

Department of Economics

Louisiana State University

2439 BEC

Baton Rouge, LA 70803-6306

and NBER

mocan@1su.edu

Han Yu

Department of Economics

Louisiana State University

2416 BEC

Baton Rouge, LA 70803

hyu17@1su.edu 


\section{Can Superstition Create a Self-Fulfilling Prophecy? School Outcomes of Dragon Children of China}

\section{Introduction}

Cultural beliefs and preferences impact the behavior of individuals who hold these beliefs. For example, the strength of family ties, based on cultural heritage, negatively influence political participation and civic engagement (Alesina and Giuliano 2011); labor supply and fertility rates in a woman's country of ancestry have explanatory power in determining work and fertility decisions (Fernandez and Fogli 2009), and cultural preferences towards leisure have an impact on the labor market activity of women (Mocan forthcoming). The extent to which residents of a country consider people of another country as untrustworthy has an influence on trade and foreign direct investment between these countries (Guiso et al. 2009).

Beliefs and behaviors, even those that can be thought of as having been engrained in the fabric of culture, react to the economic and institutional environment (Mocan, Bielen and Marneffe 2018, Mocan and Raschke 2016, Alesina, and Fuchs-Schündeln, 2007, Di Tella et al. 2007). Yet, there is substantial persistence in beliefs over long periods of time, and beliefs are transmitted through generations (Voigtlaender and Voth 2012; Guiso, Sapienza and Zingales 2008). Such persistence raises the question of whether cultural beliefs, even if they are completely untrue, can be self-fulfilling. For example, Nunn and Sanches de la Sierra (2017) describe a superstitious belief which has emerged in the Democratic Republic of Congo regarding how to become a bulletproof person through a ritual. They show that, although untrue, this belief helped villagers coordinate their defense activities against a group of bandits who possessed firearms, and it allowed the villagers to 
defeat the bandits. Even though some villagers died in the process because the ritual never made them bulletproof, that most people believed in this superstition generated a mass movement of organized and successful defense against the perpetrators, which then reinforced people’s beliefs in this particular superstition.

In this paper we investigate whether a cultural belief about the characteristics of a group of people is self-fulfilling, and we analyze the mechanism which is a source of this self-fulfilling belief. We focus on the wide-spread belief in Asian cultures that people born in certain zodiac years are inherently different from those born in other years. Specifically, in China people born in Dragon years are believed to be superior, powerful and destined for good fortune.

Because there is no biological reason for people who are born in a certain time period be more successful economically in comparison to those who are born in adjacent time periods, it is surprising that this superstition has persisted for centuries. In a related domain, researchers started exploring the production of, and the reasons for persistence of "motivated belief distortions," including such concepts as wishful thinking and willful blindness (Benabou and Tirole 2016, Benabou 2015). For example, Benabaou and Tirole state that "People thus hold certain beliefs in part because they attach value to them, as a result of some (usually implicit) tradeoff between accuracy and desirability. Such beliefs will therefore be resistant to many forms of evidence, with individuals displaying nonBayesian behaviors such as not wanting to know, wishful thinking, and reality denial.”

We first analyze province level panel data from China and find that the number of marriages goes up during the two years before a Chinese Dragon year, arguably because newly-wed parents would like their offspring to be born in a Dragon year. Consistent with 
this conjecture, using province panels we also show that the number of births rise in Dragon years.

If the cohort size of Dragon children is larger because of parents' demand for a "Dragon child" and the resultant increase in the number of birth in Dragon years, this would intensify competition among children of that cohort in terms of educational resources. For example, class sizes in schools would be larger for kids born in Dragon years, which may reduce the quality of education they receive. Similarly, competition for a slot in a highquality college, and competition for good jobs could be more intense because kids born in Dragon years would have to compete with a larger group of same-age peers. If this is the case, and if children born in a Dragon year have worse educational outcomes in comparison to their peers who are similar in age and in other attributes, this would beg the question of how this particular belief about Dragon children being destined for good fortune greatness could persist. ${ }^{1}$

Against this backdrop, we investigate whether educational outcomes of Dragon children are different from that of their peers. We analyze two separate micro data sets and find that students born in Dragon years are more likely, as opposed less likely, to receive higher scores in the national college entrance examination, and that they are more likely to have attained at least a college education in comparison to similar individuals who are of

\footnotetext{
${ }^{1}$ Suen (2004) shows that in a Bayesian framework if information is difficult to obtain or if the person receives information from like-minded people who provide coarse information, then the existing priors (beliefs) are reinforced, and incorrect beliefs can persist. Agarwal et al. (2017) show that the number of births among the Chinese minorities in Singapore increases during the year of the Dragon. Given the small size of the city-state and limited capacity of educational institutions, this increase in the cohort size makes it more difficult for Chinese Dragon children to get admitted to two top universities in Singapore. The income levels of Dragon Children are also lower in Singapore.
} 
the same age (or who are very similar in age), but who have different zodiac year designations.

When we analyze a third data set that contains detailed information on middle school students we find that the same pattern exists in middle school. Middle school students who are born in a Dragon year have higher test scores in comparison to other students who are of the same age or similar in age, holding constant many determinants of test scores.

We also conduct analyses in narrow samples that compare individuals who are born a few months apart. The year of the Rabbit precedes the year of the Dragon in the zodiac calendar, and Snake year follows the Dragon year (see Figure 1). We compare those who are born in the last full month (or months) of the year of the Rabbit to those who were born in the first full month (or months) of the year of the Dragon, as well as those who were born at the end of the Dragon year to those born in the beginning of the year of the Snake. We also conduct a sharp Regression Discontinuity analysis when the data set contains the exact birth dates. Although sample sizes go down considerably in these analyses, the inference is not altered.

In all three data sets we find that parents of Dragon children and parents of other children have similar educational attainment. The same is true regarding family income and the propensity of parents having white collar jobs. This suggests that the differential educational success of Dragon children is not related to family background. Better educational outcomes of Dragon children cannot be related to teacher behavior either because it is unlikely for teachers to know the exact birth dates of their pupils to determine their zodiac, and the university entrance exam scores are graded with no information about student identity. 
One potential mechanism that can generate better educational outcomes for Dragon children is higher self-esteem of these children. If children born in Dragon years believe that they are superior to other children and if Dragon children have higher self-esteem, this could impact their success in school as higher self-esteem and confidence may lead to better learning. The data set on middle school children allows us to analyze this potential channel because it includes questions designed to gauge the self-esteem of the students and their aspirations about their own future. We find that students who are born in a Dragon year do not consider themselves as having higher ability than other students. Similarly, Dragon children in middle school are not more likely to believe that they will have a successful future.

On the other hand, we find that the parents of these Dragon children have substantially higher expectations of their children regarding their children's educational attainment and about their children's future success in comparison to other parents. In addition, we find that parents of Dragon children invest more heavily in their children compared to other parents in terms of time and money. Importantly, we find that the "Dragon impact" on test scores disappears once we control for parents' expectations about their children's future. This indicates that the educational success of Dragon children is driven by parent expectations and parent investment.

If parents of Dragon children believe that their children are inherently more productive as suggested by the superstition, they would invest heavily in their kids in comparison to other parents because the return of their investment is higher. It can be argued, however, that parents of Dragon children do not believe in the superstition. They want their kids to be born in a Dragon year for some other reason, but they don't actually 
think that Dragon kids are destined for greatness. ${ }^{2}$ Yet, they recognize that the Dragon cohorts are larger and therefore their children would be at a disadvantage unless additional resources are allocated to these kids to compensate for the intensity of competition they would face due to the large cohort size. Under this conjecture, Dragon parents invest in their children to counteract the drawback of their kids being a member or a large cohort. We provide evidence in the paper against this hypothesis. In the middle school data set the $7^{\text {th }}$ grade consists of only those students who were born in a Dragon year or in a Snake year. This cohort of the $7^{\text {th }}$ graders is large because of the Dragon children, and the parents of the Snake children are presumably aware of this fact. Thus, the parents of the Snake children should be similarly worried about the increased competition due to the large cohort size and therefore they too should invest in their kids. This means that there should not be a significant difference between the two groups of parents in terms of investment in their children. However, analyzing this group of Dragon and Snake parents whose children are classmates, we find that Dragon parents' beliefs and behaviors are significantly different from those of the Snake parent. Dragon parents have higher expectation of their children's future than the parents of Snake children whose kids are in the same classrooms. Furthermore, Dragon parents invest significantly more in their children in comparison to Snake parents. Unless one is prepared to argue that parents of Snake children do not care about the success of their offspring, this finding refutes the conjecture that Dragon parents invest in their kids because they are worried about the competition with a large number of students in the cohort.

\footnotetext{
${ }^{2}$ As discussed earlier, we show in the paper that Dragon parents have, in fact, higher expectations of their children in comparison to other parents, refuting this claim.
} 
Finally, although we show that parents of Dragon children are no different from other parents in observable ways, they could be different in ways we don't observe as researchers. For example, it could be that mothers of Dragon children are more cognizant of the positive impact of a healthy pregnancy on birth outcomes, and therefore on the long-run benefits for their children. As a result, expectant mothers of Dragon babies may have consumed more health inputs such as medical care and nutritious foods during pregnancy to improve the health of their baby. The most widely-used indicator of health at birth is the birth weight of the baby. Research, however, has shown that an increase in birth weight has only a modest impact on schooling and test scores. ${ }^{3}$ This indicates that any potential investment in child health by parents of Dragon babies during pregnancy, and the resultant increase in birth weight, is unlikely to be a primary factor that drives the difference in educational outcomes between Dragon children and others. ${ }^{45}$ Any potential investment avenue that

\footnotetext{
${ }^{3}$ For example, Royer (2009) uses data from California and finds that a one-kilogram increase in birth weight (which is a very substantial increase, given the mean birth weight in the population is about 3,500 grams) is associated with an additional 0.16 years of schooling. Using Florida data, Figlio et al. (2014) find that a one kg. increase in birth weight generates an increase in schooling by 0.156 years. The authors also show that the same 1,000 gr. increase in birth weight is associated with less than $1 / 20$ of a standard deviation increases in tests scores in grades 3 to 8 . Bharadwaj et al. (2018) use data from Chile and report that at 10 percent increase in birth weight (which corresponds to a 250-gram increase) raises test scores in math and language by 0.04-0.06 standard deviations. Using Chinese data Rosenzweig and Zhang (2013) find that an increase in birth weight by one standard deviation (about $0.48 \mathrm{lbs}$, or $220 \mathrm{gr}$ ) is associated with increase in a combination of math and language grades of students ages $12-15$ by 2.3 to 3.5 percent.

${ }^{4}$ One mechanism through which birth weight can impact school outcomes is through the potential influence of birth weight on cognitions. The research on the impact of birth weight on IQ, however, is not conclusive (Cook and Fletcher 2015, Newcombe et al. 2007). In our data set, there is no difference in the cognitive test scores between Dragon children and other middle school children.)

${ }^{5}$ Furthermore, that we find a significant relationship between Dragon parents' expectations of their kids' academic professional achievement and the investment parents make in their kids, and that these parent expectations explain the difference in test scores between Dragon kids and other kids, does not rule out other ways Dragon parents can help their kids fulfill these expectations.

For example, it could be that when Dragon parents invest in their kids in ways we measure in this paper (talking to the classroom teachers more frequently, not asking their kids to help with house
} 
may have been utilized by parents since the birth of their children does not alter the message of this paper: Even though children born in a Dragon year are no different from other children in the dimensions we observe in our data, ranging from family background to selfesteem, and expectations and aspirations about their future, these students are more successful in school. This is because the parents of Dragon children have higher expectations of their children and they invest in their children more intensely. In the end, these higher expectations yield better educational outcomes. Put differently, these expectations and the ensuing investment create this self-fulfilling prophecy.

Do and Phung (2010) show that in Vietnam children born in auspicious years have two more months of schooling, and the authors attribute this outcome to the wantedness of the children and the planning of these births by the parents. Thus, a hypothesis is that some parents have high expectations of their children and they invest heavily in their children, and that these parents also time their pregnancy so that their children are born in the year of the Dragon. This is not because these parents necessarily believe in the superstition, but “just in case.” In this scenario children are born in the Dragon year not primarily because of parent superstition, but mainly because their parents are investor and planners, (including planning the timing of the birth in a Dragon year). Such a conjecture, of course, begs the question of why non-superstitious parents time the birth of child of their children to coincide with the Dragon year after all. Nevertheless, if this is the dominant behavior, parent expectations of children and the outcomes of these children should be similar in a narrow window on both sides of Dragon zodiac cut-off. Put differently, parents who made slight timing errors in pregnancy should be similar to parents who timed their pregnancy

chores, etc.), they could also invest in their children in other ways at the same time, such as by buying books and computers for their children, hiring tutors for them, and so on. 
accurately. The same should be true for the children of both types of parents. We show that this is not the case. There are significant differences in parent expectations and student outcomes between those who are born in the last month of the Dragon year and those who are born just one month later.

In Section II we provide the background regarding the belief on zodiacs in the Chinese culture. Sections III and IV present some stylized facts showing the existence of preferences for Dragon kids in China using national and provincial panel data. Empirical framework is explained in Section V. The data used in the paper are presented in Section VI, and the empirical results are reported in Section VII. Section VIII presents the analyses of narrow samples which consist of individuals born in nearby months. Section IX is the conclusion.

\section{Background and Previous Literature}

In traditional Chinese culture and in Asian cultures generally, there are 12 creaturezodiacs, which represent different characteristics of the cohorts born in different Chinese lunar years. The order of the zodiacs, depicted in Figure 1, are Rat, Ox, Tiger, Rabbit, Dragon, Snake, Horse, Sheep, Monkey, Rooster, Dog and Pig. The zodiacs follow Chinese lunar calendar, and each zodiac appears approximately every 12 years. For example, the Dragon year of 1988 started on February 17, 1988 (the first day of 1988 in Chinese lunar calendar) and ended on February 5, 1989 (the last day of 1988 in Chinese lunar calendar). Following a 12-year cycle, another Dragon year covered the time span between February 5, 2000 and January 23, 2001. ${ }^{6}$

\footnotetext{
${ }^{6}$ Therefore, if a child was born in 1988, the child's zodiac sign could be Rabbit (the zodiac before Dragon) or Dragon depending on the specific date of his/her birthday. Similarly, if a child was born
} 
Of these 12 creatures, Dragon is considered as special because of its place in the legends and mysteries. Dragon is a symbol of auspiciousness and power in Chinese culture. One adage in Chinese states “wang zi cheng long”, which can be literally interpreted as "hope that my children become Dragons." Chinese people believe that babies born in a Dragon year will have better fortunes than babies born in other years.

There is evidence, reported by previous work, that in many Asian countries the fertility rate goes up during dragon years. Vere (2008) reported that the number of live births in Hong Kong increased significantly in the years of 1988 and 2000 which were two Dragon years. Agarwal et al. (2017) found an increase in fertility among the Chinese minorities in Singapore increases during the year of the Dragon. The same pattern in birth rates was found among Chinese in Taiwan, Singapore, Malaysia and the U.S., ${ }^{7}$ suggesting that people of Chinese heritage indeed time the birth of their offspring to coincide with the Dragon years. Yet, no evidence was found in mainland China to indicate the existence of birth timing for Dragon children. Goodkind (1991) argued that compared to Taiwan, Hong Kong, and Malaysia, local institutional conditions in China in the 1970s and 1980s, the Cultural Revolution between 1966 and 1976, and China's birth control policies were factors that prevented China from experiencing baby booms in the Dragon years of 1976 and 1988. During the period of Cultural Revolution, any activity connected with superstition was strictly forbidden, and the One Child Policy had been implemented in China starting in the late 1970s. According to the policy, each couple was allowed to have

in 1989, the zodiac sign of this child may be Dragon or Snake (the zodiac after Dragon), again depending on the specific date of birth.

${ }^{7}$ Also see Sim (2015), Yip et al. (2002), Wong and Yung (2005), Johnson and Nye (2011), and Goodkind (1991). 
only one child, and if a couple just missed a Dragon year to have a baby, it would be hard for them to plan for a Dragon baby unless they were willing to wait for 12 years to have a child. Nevertheless, along with the process of becoming more open, the Dragon symbol became acceptable in China again (Goodkind 1991). ${ }^{8}$

As explained in the next section, we show that despite these institutional barriers, parents in mainland China do in fact time the birth of their children. Using national and provincial data on live births we show that the number of live births spiked in the two most recent Dragon years (2000 and 2012) ${ }^{9}$. We also show that the number of marriages goes up during the two years before a Dragon year, which supports the conjecture that couples try and time their marriages and the subsequent pregnancy so that the birth of their child would coincide with the Dragon year.

A handful of studies have examined whether people born in Dragon years have better “fortunes” and reported conflicting results. Using census datasets from Hong Kong, after controlling for education, Wong and Yung (2005) did not find a significant correlation between being born in a Dragon year and labor income. Sim (2015) suggested that due to the large number of new babies born in the Dragon year of 1976 in Singapore, the Dragon cohort should face higher competition when they apply for universities. He found a negative impact of being born in the year of 1976 and 1977 on the probability of obtaining

\footnotetext{
${ }^{8}$ The One Child Policy of China has been relaxed over the years. Starting in 1984, parents were allowed to have a second child as long as both parents were single children themselves. In 2013 the policy has been revised further to allow parents have a second child as long as one of the parents was a single child him/herself. Furthermore, parents can always have more than one child if they are prepared to pay a monetary penalty or lose their government job.

${ }^{9}$ Our finding indirectly supports the argument of Goodkind (1991). It seems that when local institutional conditions got better and when the impacts of the Cultural Revolution gradually faded away, the favor of Dragon children re-appeared in mainland China.
} 
a college degree in Singapore, although the results need to be interpreted with caution due to the very small sample size employed and the specific way how the Dragon cohort was defined. ${ }^{10}$ Johnson and Nye (2011) compared Asian immigrants to the U.S. to non-Asian immigrants and reported a positive impact of being born in a Dragon year on educational attainment among Asian immigrants. ${ }^{11}$ Do and Phung (2010) found that in Vietnam, children born in years that are thought to be auspicious have more years of schooling. Agarwal et al. (2017) reported that income levels of Dragon Children were lower in Singapore. They attribute this finding to the increase in cohort size due to the jump in birth in Dragon years, which puts downward pressure on earnings given inelastic labor demand. Lau (2019) shows that there was spike in fertility in Hong Kong during the Dragon years of 1988, and using a diff-in-diff analysis he finds that both Dragon and non-Dragon

\footnotetext{
${ }^{10}$ In Sim (2015), the "Dragon cohort” is defined as all those born in 1976 and 1977. According to the Chinese lunar calendar, the Dragon year of 1976 started on January 31, 1976 and ended on February 17, 1977. This means that the "Dragon cohort" in Sim (2015) included not only Dragons but also Rabbits (the cohort right before a Dragon cohort) and Snakes (the cohort right after a Dragon cohort). Therefore, the negative "Dragon effect" on college entrance does not indicate that the Dragon cohort but the mix of three cohorts had lower propensity of getting into a college in Singapore on average. The author defined the "Dragon cohort" in this way to address that people born in 1976 and 1977 all have to face the competition brought by the baby boom in the dragon year of 1976. The author also mentioned that in the analysis sample, the Dragon cohort was on average better educated in the sense that a higher proportion of the Dragon cohort were college graduates in their sample compared with that among other cohorts.

${ }^{11}$ It is, however, difficult to interpret the results Johnson and Nye (2011). In the CPS data used in the paper, the authors classify the "treated" group as those (i) who reported their race as Asians, and (ii) who should culturally believe in the Dragon superstition. To arrive at the proper treated group the authors correctly drop certain Asians such as Pakistanis, Indians and Filipinos from this group, but they also drop mainland Chinese, although this latter group should be the most impacted by the Dragon superstition. In the other data set used in the paper (the 2000 Census data), the authors restrict the sample to the residents of California who reported their race as Asian, and define the treatment dummy as being equal to one for those who reported their place of birth as Taiwan. Thus, in these models, those with Chinese heritage are placed in the control group and thus they are considered as being not impacted by the Dragon superstition (Johnson and Nye 2011, p. 95). Other issues include admitted misclassification of the Dragon variable (footnote 10, and p.95), and the very small number of Dragons in the analysis of mothers (34 individuals in a sample of 14,344, and 116 people in the sample of 48,253; p. 92).
} 
students of that Dragon-year cohort increase their time spent studying math, arguably because of competitive pressures of being part of a larger peer group.

\section{Aggregate Fertility and Zodiacs in China}

Figure 2 presents the annual number of live births in mainland China between 1995 and 2014, obtained from China Health Statistical Yearbook. ${ }^{12}$ Live births jumped up significantly in 2000 and 2012 which are the two most recent Dragon years. Specifically, the number of live births increased by 289,224 in 2000 compared to the year prior, and by 935,854 in 2012 compared to 2011. Even after the implementation of a new policy at the end of 2013 allowing parents to have a second child as long as one of the parents was a single child in his/her family, the number of babies born in China in 2014 was still much lower than that in 2012, which was a Dragon year.

To more formally analyze the impact of Dragon years on birth as well as marriages, we employed province level panel data on the number of marriages and the number of live births. ${ }^{13}$ The results, reported in the Appendix Table A1, indicate that more people get

\footnotetext{
${ }^{12}$ We use the actual number of births rather than the birth rate because population data that are used to calculate the birth rate information provided by the Chinese Statistical Yearbook or by the National Bureau of Statistics of China, are inconsistent over time and across regions, and not reliable. Population figures are estimated using different sources (some from household registrations, some from census estimates, some others from annual national surveys on population changes). In contrast, the data we use are the actual number of live births provided by the China Health Statistical Yearbook.

${ }^{13}$ Using data on the number of marriages newly registered by the government every year between 1979 and 2013, we investigate whether couples are more likely to get married before a Dragon year (so that it would be easier for them to have a Dragon baby). Similarly, using province-level data on live births, we are able to analyze whether more babies were born in Dragon years. The provincial marriage data are from the China Civil Affair's Statistical Yearbook 1979-2014. The data are available for the period of 1978 - 2013. The provincial live births data are available for the year span from 2003 to 2013, collected from the China Health Statistical Yearbook 2004 - 2014. Because the Chinese zodiacs follow the Chinese lunar calendar but the provincial data on the number of marriages and live births follow the Gregorian calendar,
} 
married in a Tiger year and a Rabbit year, which are the two consecutive years before the Dragon year. This is presumably because getting married within two years before a Dragon year makes it easier for couples to plan for a Dragon baby. The results also show that more births are given in a Dragon year. Thus, Chinese who live in mainland China care about the zodiacs and that they time both their marriages and the birth of their children accordingly, and that about half a million more babies are born in a Dragon year in comparison to other years.

\section{Empirical Framework}

To investigate the relationship between having been born in a Dragon year and educational achievement, and the potential mechanisms of such a relationship, we employ three different data sets and estimate the following three models below.

Using data from the Chinese General Social Survey (CGSS) we estimate

$$
\text { College }_{i}=\alpha_{1}+\beta_{1} \text { Dragon }_{i}+\gamma_{1} \mathrm{X}_{i}+\theta_{c}+\xi_{i}
$$

where Colle $_{e} e_{i}$ is a dummy variable indicating whether individual $i$ has attained a college education or higher. $\operatorname{Dragon}_{i}$ is a dummy variable indicating that an individual was born in the Dragon year. As explained in the Data Section below, the CGSS contains information on the exact date of birth of the respondents; thus their Zodiac affiliation can be determined

and because the two calendars do not overlap perfectly, an adjustment needs to be made to the reported births and marriages. For instance, we let Dragon $=(366-31-4) / 366$ for the year 2000 . This is based on the fact that the entire month of January and the first 4 days in February of 2000 do not belong to the Dragon year. Therefore, only (366-31-4) days in the year of 2000 (there are 366 days in 2000 since the year of 2000 is a leap year) belong to the Dragon year. We let Dragon take the value of 23/365 in the year 2001 because the first 23 days in 2001 were still inside the range of the Dragon year. We define Tiger and Rabbit similarly. We control for per capita income of the province to account for the impact of economic conditions, and province-level unobservables are accounted for by province fixed effects and province-specific linear trends. The data are from 30 provinces/municipalities of China, spanning the years 1979 to 2013. 
with precision. $\mathrm{X}_{i}$ stands for a vector of controls, including gender, age, ethnicity, parents' educational level as well as occupation and survey wave dummies; $\theta_{\mathrm{c}}$ stands for province fixed effects, and $\xi_{i}$ is the error term.

In the second set of regressions we utilize the Beijing College Students Survey (BCSS) data to investigate whether Dragon children perform better in the National College Entrance Examination in comparison to other children. Specifically, we estimate

(2) CollegeEntranceExamScore $e_{j}=\alpha_{2}+\beta_{2}$ Dragon $_{j}+\gamma_{2} \Lambda_{j}+\rho_{s}+v_{j}$ where CollegeEntranceExamScore $j_{j}$ is college student $j^{\prime} s$ score in the National College Entrance Examination. Dragon $_{j}$ is a dummy to indicate that student $j$ was born in a Dragon year. $\Lambda_{j}$ stands for a set of controls including the student's gender, ethnicity, parents' educational level, family's economic condition and whether the student took the National College Entrance Examination multiple times. ${ }^{14}$ Although the college entrance examination is a national exam in China, the questions differ between provinces and municipal cities in different years. To account for differences in educational quality, we include province fixed effects, $\rho_{s}$. Due to the design of the survey, all students surveyed took the exam in either 2006 or 2008; thus, the model also controls for the year in which the student took the exam.

In the third set of analyses, we examine the relationship between having a Dragon zodiac and the test scores among middle school students by making use of the China Education Panel Study (CEPS) data. We estimate regressions of the form:

\footnotetext{
${ }^{14}$ We also have information on whether the student graduated from an elite high school. Although we do not include this variable as a control as it could be endogenous if Dragon status determines the type of high school the student attends, controlling for this variable does not influence the results.
} 


$$
\text { TestScore }_{k s}=\alpha_{3}+\beta_{3} \text { Dragon }_{k}+\gamma_{3} \Theta_{k}+\lambda_{c}+\mu_{k}
$$

where TestScore $_{k s}$ is the mid-term test score of student $k$ in subject $s$, where the subjects are Mathematics, Chinese and English. Dragon $_{k}$ is a dummy variable equal to one if student $k$ was born in a Dragon year. $\Theta_{k}$ is the vector of control variables, including the attributes of the students such as age, gender, type of hukou, ${ }^{15}$, ethnicity, whether they are the only child in their family. ${ }^{16}$ Also included in the data set are parents' characteristics, ranging from parents' education to whether parents have white collar jobs, to the income level of the family, reported by parents. $\lambda_{c}$ stands for a set of classroom fixed-effects, and $\mu_{k}$ is an error term. Standard errors are clustered at the classroom level, with 438 classrooms.

Using the same CESP data, we also run models depicted by Equation (3), but we employ as dependent variables those that gauge the extent of students' self-esteem and aspirations, reported by the students. These dependent variables include the following six separate indicators that measure if the student believes he/she is (i) articulate, (ii) fast thinker, (iii) quick learner, (iv) has faith in his/her future, (v) wants to go to college, and (vi) if s/he expects to be a leader or officer in national/government institutions, a scientist, an engineer or an executive in a company.

We similarly analyze the extent to which parents' expectations regarding their children’s future are different between parents of Dragon-year children and other parents.

\footnotetext{
${ }^{15}$ Hukou can be understood as a certificate of residency in China. It is correlated with people's choices and rights in terms of housing and schooling.

${ }^{16}$ The CEPS data provide information on students' cognitive ability. The baseline regressions do not include this variable as cognitive ability may be "determined" by the zodiac of the student if cognitive ability measures, in part, skills learned at school or in the family. Adding cognitive ability to the model, however, has no impact on the results.
} 
These regressions follow the same format as Equation (3), but the dependent variables include such measures as whether the parent expects his/her child to obtain at least a college degree, whether the parent expects the child to get a job in the future as a leader or officer in national/government institutions, a scientist, an engineer or an executive in a company, and whether the parent has faith in the child's future.

Finally, we investigate parents' investment in their children. The questions we use include whether the child went to kindergarten ${ }^{17}$, the amount of pocket money parents give to the child (in middle school), how many times parents talked to the teachers this semester, and whether the kids do any chores at home, helping parents.

It is conceivable that the parents of Dragon children are systematically different from other parents. For example, they can be more educated, or they can have more income. In all data sets we used, we investigated whether Dragon parents differ from other parents in observable dimensions, ranging from parent education to occupation and family income. As explained later in the paper, there is no difference between the two groups of parents in terms of these attributes and controlling for these attributes in regressions does not alter the results.

\section{Analyses of Individuals who are around the Zodiac Cutoffs}

We supplement the analyses described earlier with additional investigation of the outcomes (i.e. education level, university entrance exams, middle school test scores) using individuals who are at both ends of the Dragon year cutoffs.

\footnotetext{
${ }^{17}$ In China children are not allowed to enter kindergarten before they are 3 years old.
} 
Using the CGSS data, we implement a sharp regression discontinuity (RD) design (Imbens and Lemieux 2008, Lee and Lemieux 2010) taking advantage of the information on the exact birthdates of the survey respondents. Our preferred specification is the local linear regression without specifying a functional form on the data. ${ }^{18}$ To estimate the causal impact of being born in the Dragon year on the propensity of earning a bachelor's or higher degree, we estimate the following local linear regression equation:

(4) $Y_{i}=\alpha_{4}+\beta_{4} D_{i}+\beta_{5}(\text { birthdate }- \text { cutoff })_{i}+\beta_{6} D *(\text { birthdate }- \text { cutoff })_{i}+\gamma_{4} K_{i}+\varepsilon_{i}$

where $Y_{i}$ is the outcome, and $D_{i}$ is the Dragon dummy. The running variable is the birthdate of the individuals.

Because the Dragon year has two cutoffs at the beginning and the end of the year, each individual in the sample faces two potential cutoffs. Following Pop-Eleches and Urquiola (2013), Hoekstra et al. (2018), and Zimmerman (2019), we utilize both cutoffs in the analyses. ${ }^{19}$ We allow for different treatment effects on both sides of the cutoff by interacting the Dragon dummy with the distance between the birthdate and cutoff date. The coefficient of interest, $\alpha_{1}$ in Equation (4), measures the effect of being born in the Dragon year on the outcome. $K_{i}$ is the same full set of covariates included in Equation (1), and $\varepsilon_{i}$ is the error term. The optimal bandwidths are selected by the data-driven procedure developed by Calonico et al. (2017) and Calonico et al. (2018) for both sides of the cutoffs

\footnotetext{
${ }^{18}$ As suggested by Gelman and Imbens (2017), local linear regressions (non-parametric) are more stable in uncovering the true estimates than polynomial models because polynomial models are prone to providing noisy estimates. Moreover, estimates obtained from polynomial models could be sensitive to the degree of the polynomial. Nevertheless, we also provide the RD estimates obtained from the first and second order polynomials (parametric) in the Appendix.

${ }^{19}$ We replicate each observation in the original working sample once. Consequently, each individual is presented twice in the sample. We employ the two observations of each individual for the two cutoffs, respectively. In practice, however, each individual is only utilized once in the analysis.
} 
separately with a uniform kernel, but employ various bandwidths to investigate the robustness of the results. ${ }^{20}$ The RD results are presented in Section VII.

In the BCSS and CEPS samples we are not able to implement an RD estimation because although the month of birth in reported, the birthday is not recorded. In the same spirit of local linear regressions, however, we implement analyses using individuals born in the nearest full months to the cutoffs. For example, a Dragon year started on February 17, 1988 and ended on February 5, 1989. The year before the Dragon is a Rabbit year and the year after the Dragon is a Snake year. Thus, using the BCSS data we run the models using those who were born in the last full month of a Rabbit year (born too early to have a Dragon zodiac) and those whore born at the first full month of the Snake year (born too late and missed being a Dragon) as well as the Dragons who were born in the first and the last full month of the Dragon year. We conduct a similar analysis using the CEPS data. Although the sample sizes decline by design, we obtain the same inference.

\section{Data}

\section{Chinese General Social Survey Data.}

We construct separate datasets based on three newly released surveys from China. The data employed to analyze the educational level of the Dragon cohort are obtained from the Chinese General Social Survey (CGSS). CGSS is a large and nationally representative social survey that covers all provinces, and both rural and urban areas in China. We use the 2010, 2012, 2013, and 2015 waves of CGSS because the exact birthdates of the respondents are provided in these waves, which allows for the determination of their zodiacs accurately.

\footnotetext{
${ }^{20}$ We also estimate specifications using a triangular kernel using various bandwidths, which provide similar results, reported in Panel B of Appendix Table A5.
} 
In addition, these four waves include consistent measurement of parents' employment status. We restrict our data to the survey respondents who were born between 1985 and 1991 (1988 is the Dragon year). Hence, in our effective sample the age of the respondents ranges from 19 to 30 . In alternative specifications, we narrow the age window to those who are born between 1986 and 1990 and between 1987 and 1989. For example, Figure 3 displays the proportion of individuals with a college degree or higher by their zodiac year and it shows that the Dragon cohort is more likely to have a college education than the Rabbit and Snake cohorts who were in the same academic years with the "Dragons."

Table 1 presents the summary statistics of the CGSS dataset. The total number of observations is 3,835. The dataset covers one Dragon cohort (the Dragon year of 1988). As shown in Table 1, the Dragon and non-Dragon cohorts are similar in attributes such as gender, ethnicity, and parent education.

\section{Beijing College Students Survey Data}

The second data set is the Beijing College Students Survey (BCSS), which we use to examine the relationship between having a Dragon zodiac and students’ performance in the National College Entrance Examination in China (see Equation 2 above). Around 5,000 students from 15 universities in Beijing were randomly selected to answer the survey in 2009 (Li, 2016). ${ }^{21}$ Students were asked to report when they took the National College Entrance Examinations and what their scores were.

\footnotetext{
${ }^{21}$ Almost all the universities in the sample are top 50 schools in China. Only one of them has a rank of 52.
} 
The summary statistics of the BCSS dataset are presented in Table 2. Our effective sample contains 2,956 observations. Twenty-three percent of the students were born in the Dragon year of 1988. In various specifications estimated we created sub-samples with narrower age bands. For example, we focused on those born in the Dragon year (1988), those born the year before (1987) and the year after (1989).

Due to the design of the survey, students in the sample took the national entrance exam in either 2006 or 2008, and we restrict the sample to students who took the exam when they were 18 or 19 years old, which is the typical age when a high school graduate takes the college entrance exam in China. Students whose score is lower than 500 points are dropped and students from Hong Kong, Taiwan, Macaw and Tibet are dropped ${ }^{22}$.

As shown in Table 2, twelve percent of students belong to a minority group in China, and 10 percent of them took the National College Entrance Examination more than once. The students were asked to rank the income status of their family in their local area, from 1 to 5 indicating from the best to the worst. We create a dummy variable to indicate that the economic status of the student's family is good. This variable takes the value of one if the respondent indicated that his/her family's economic condition is the best in the local area, or better than local average income. Table 2 shows that 15 percent of students indicated that their family income can be classified as such. Table 2 also shows that the

\footnotetext{
${ }^{22}$ Every year in each province in China, there is a minimum cutoff point which determines whether a student can go to a "key" college in China. All the students in our sample are from top colleges where the cutoff scores are usually much higher than the cutoff point for "key" colleges. Because the lowest minimum cutoff point in 2006 and 2008 was higher than 500 points in most of the provinces, we therefore drop students whose scores are below 500 points. For the similar reason, we drop students who took the exam in Shanghai, Guangdong or in Jiangsu province in 2008, because the total score in Shanghai, Guangdong or in Jiangsu in 2008 are much different from those in other provinces, which make their students incomparable to others students.
} 
average college entrance exam score is about 603, and Figure 4 reveals that those with a Dragon zodiac have higher scores in comparison to individuals with other zodiac affiliations.

\section{Middle School Students: China Education Panel Study Data}

The third data set analyzed is the China Education Panel Study (CEPS). The CEPS sampling design is based on randomly selecting 438 classrooms from 112 schools in 28 districts, counties or cites, after the first-stage stratification by education level and intensity of population mobility. In the main analyses, we use the first wave of CEPS, which is conducted in 2013-2014. CEPS collects data on middle school students in grades of 7 and 9, who were born in 1996-2002. Consequently, we have a Dragon cohort (spanning February 5, 2000 to January 23, 2001).

As shown in Table 3, of approximately 15,000 middle school students in our sample, 23 percent were born in the Dragon year of 2000. About half of the students are female. The data set contains the mid-term test scores in the subjects of Math, English and Chinese. The mid-term exam scores are provided by the head teacher of the class or the dean of studies in these middle schools.

A unique aspect of this data set is the questions about self-esteem and expectations about the future. The students answered questions measuring their self-esteem and ambitions and expectations about their future. Specifically, students are asked to evaluate statements about themselves by providing a rating to each statement, ranging from 1 "Completely disagree" to 4 "Completely agree". The dummy variable Articulate takes the value of 1 if the student "completely agrees" or "agrees" with the statement that "I can express my opinions clearly.” Fast Thinker is another dummy variable that takes the value 
of 1 if the student completely agrees or agrees with the statement of "I respond quickly to things”. Quick Lerner takes the value of one if the student believes that s/he can learn new knowledge quickly.

The students were also asked to evaluate the extent of their faith in their own future. Possible answers range from "I have no faith at all in my future" to "I have a lot of faith in my future.” We build a dummy to indicate that a student has some faith or a lot of faith in his/her future. In addition, the survey asks the students what degree they would like to obtain and what kind of job they would like to have in the future. The variable Wants College Degree or Higher takes the value of one if the student wishes to obtain at least a college degree. We define Strong Career Ambition as a dummy variable indicating whether a student expects to have a job as a leader or officer in national/government institutions, a scientist, an engineer or an executive in a company.

The CEPS also asked parents about their expectations for their children. We create a dummy variable to indicate that parents expect their children to have at least a bachelor's degree based on the question: "what degree do you expect your children to achieve?" Parents are also asked the question "what occupation do you expect your children to have in the future?” We created a dummy variable to indicate whether parents have strong career ambition for their children, revealed by their expectation of their children becoming a leader or officer in national/government institutions, a scientist, an engineer or an executive in a company. Another dummy takes the value of one if parents are "confident" or "very confident” that their children are going to have a bright future. We also constructed a dummy variable to indicate whether parents expect of their child to perform better than class average. 
We created a set of dichotomous indicators that measure various aspects of parents' investment in their children. For example, we created a dummy variable to indicate whether parents contact the teachers of their kids frequently in the current semester. We also built a variable which measures the amount of pocket money given to the kids each week by their parents. The CEPS survey asks the students whether they usually help parents in housework and during the summer/winter holiday. A similar question asks the students how much time they spent helping parents in house chores during the past week. We created two separate dummy variables indicating whether the kids help parents around the house with chores during the holiday, and whether the child help with house chores during the past week. The survey also contains a question asking the students whether they ever attended kindergarten after 3 years old. We treat the information on the kindergarten attendance as another aspect of parents' investment in children and we create a dummy variable which takes the value of one if the child attended kindergarten.

We observe in the data whether it was the mother or the father who answered the questions about parents' expectations, and we add this dichotomous indicator to the relevant regressions as a control. We drop an observation if someone other than the student’s parents (e.g. uncle or grandfather) answered the survey questions.

We have indicators for both the mother and the father having at least a college degree. Similarly, Father White Collar and Mother White Collar are two dummy variables indicating whether the father and the mother have white collar and skilled jobs. The model also includes a dummy variable gauging the income status of the family. Parents were asked about their current economic conditions of their family. The alternatives were: very 
bad, bad, intermediate, rich and very rich. The dichotomous variable Family Has High Income takes the value of one if the parent indicated that they feel rich and very rich.

\section{The Determination of the Dragon Zodiac}

To determine the zodiac of the students, the exact date of birth needs to be known. The first data set analyzed, the Chinese General Social Survey (CGSS), contains this information. The other two data sets (BCSS and CEPS) include information only on the birth year and birth month of the student, but the day of the birth is not reported. Hence, we are not able to determine the zodiacs for those students who were born in a particular month if a lunar Chinese new year started somewhere other than the beginning or the end of that month. We apply two procedures to deal with such cases in which the zodiac cannot be identified with precision. First, we treat those students as having been born in a Dragon zodiac if at least half of the month in which they were born belongs to a Dragon year zodiac. The results in the paper are based on this procedure. Alternatively, we created an adjusted Dragon dummy which takes the value of the proportion of days belonging to the "Dragon" year in that month. For example, if a student was born in February 1988, the Dragon dummy will be equal to 12/28 (there were 28 days in February of 1988; the first 16 days belong to the Rabbit year, the rest 12 days belong to the Dragon year). The results obtained from both procedures are very similar. 


\section{Results}

\section{Dragons and College Education}

Table 4 presents the results obtained by estimating Equation (1) using the CGSS data. The summary statistics of the sample are provided in Table 1 . The dependent variable is an indicator to show whether or not the respondent has attained a bachelor's degree or higher. Figure 3 displays the mean of dependent variable by zodiac for the Rabbit, Dragon, and Snake cohorts. Note that the CGSS survey is registered in different years. Thus, the respondents who are of the same age in the data may have different birth years. The regressions control for age, thus the variation in zodiac years is obtained from the incomplete overlap between the lunar and Gregorian calendars. All models contain dummies for labor market activity of both the mother and the father. These classifications include not only general categories such as full-time farming, casual worker, individual business, unemployed, retired, and housework, it also includes such categories as disabled and passed away. ${ }^{23}$

Column 1 of Table 4 shows that all else the same, those born in Dragon year have seven percentage points higher probability to have obtained a bachelor's degree or higher in comparison to individuals born in other zodiac years. When the individual's father has a college degree or higher, his/her propensity to obtain a bachelor's degree is increased by around 20 percentage points.

\footnotetext{
${ }^{23}$ The 17 categories are: 1 . Employed by others (having a fixed employer); 2.full-time farmer; 3. Part-time farmer; 4. Contract employee/dispatched worker; 5. Casual worker (no fixed employer); 6. Working in family business, with salary; 7 . Working in family business, no salary; 8 . Freelance; 9. Individual business; 10. Owner or partner of a business; 11. Retired; 12. Unemployed; 13. Disabled; 14. In school without having a job; 15. Does housework; 16. Passed away; 17. Others.
} 
The sample used in regressions reported in column (1) of Table 4 includes individuals who are born between 1985 and 1991. There is one Dragon cohort in this group: those who are born in 1988 (The Dragon year covered the period between February 17, 1988 and February 5, 1989). To create cohorts of individuals who are more similar in their birth years, we kept those who are born between 1986 and 1990. This group contains those who are born in the year of Rabbit (the year before Dragon), the year of the Snake (the year after the Dragon), the year of the Tiger (two years before the Dragon), and Horse (two years after the Dragon). The results are reported in column (2) of Table 4. The sample size goes down to 2,850, but the estimated impact of the Dragon dummy remains significant with a point estimate of 0.06. Narrowing the window of birth year to 1987 - 1989 reduces the samples size further to 1,714 in column (3), but the inference is not altered. The Dragon dummy in column (3) of Table 4, indicates that a Dragon child is six percentage points more likely to receive at least a bachelor's degree. All models contain dummies for labor market activity of both the mother and father. These classifications include not only general categories, such as full-time farming, casual workers, individual business, unemployed, retired, and housework, it also includes such categories as disabled and passed away.

In summary, consistent with the picture revealed in Figure 3, the results of Table 4 indicate that those who are born in a Dragon year are about 6 percentage points (or 19 percent) more likely to have a college education in comparison to those born in other zodiac years in cohorts that one or two years older or younger, as well as those who directly compete with the Dragon cohort in the same academic year. 


\section{Dragons and University Entrance Exam Scores}

Table 5 presents the results obtained from estimating Equation (2). The outcome is students' test scores on the National College Entrance Examinations. The descriptive statistics of the data used in these regressions (BCSS) are provided in Table 2.

The results, reported in column (1) of Table 5 show that, all else the same, the National College Entrance Examination scores of those who are born in a Dragon zodiac are around 10.5 points higher. Although this is only about 1.7 percent impact relative to the average score, this difference can have a profound effect on student placement. This is because a large population of students takes the exam each year in China, and in the extremely competitive environment each additional point has an impact on whether or not, and to which university or major the student will qualify to attend.

Table 5 also shows that female students and minorities have lower scores. In regressions not reported here, we found that those who have attended an elite high school receive substantially higher scores than students who graduate from other high schools, but that adding this (potentially endogenous) variable to the model had no impact on the estimated coefficient of the Dragon dummy ${ }^{24}$.

Column (2) of Table 5 shows that students whose parents are better educated score higher on the University Entrance Exam. The same is true if family income is above average. The magnitude of the coefficient of the Dragon dummy is reduced slightly by

\footnotetext{
${ }^{24}$ The elite high schools are called key high schools or key-point (literal interpretation) high schools. There are some key high schools in China in different jurisdictions (province level, city level, county level). The government allocates much more resources to the key high schools, such that the key high schools have more funding, better teachers, etc. Every middle school has to take a high school entrance exam to apply to a high school, and the score a student gets in this exam is the only determinant of the acceptance. Key high schools have higher minimum required scores than ordinary high schools. Some details are discussed in Ye (2015).
} 
controlling for parent education and family income. Column (3) restricts the sample to the cohorts born between 1987 and 1989; thus in this sample students differ in age by a maximum of three years. There was a Dragon year in 1988 (between February 17, 1988 and February 5, 1989). Thus, of the 2,029 students in this sample (born between 1987 and 1989), 622 (30.7\%) are born in the year of the Dragon, 666 (31.9\%) are born in the year of the Snake, and the rests are born the year of the Rabbit or Tiger. In this sample, being a Dragon child is associated with an increase in the College Entrance Exam score by about 9.1 points.

The BCSS provides information on the birth month, but not the birth date. Thus, we are unable to determine the zodiac for students who were born in the cutoff months of the Dragon year. Therefore, we employ an alternative measure of the Dragon dummy. Specifically, we let the adjusted Dragon dummy equal to the proportion of days belonging to the Dragon year if a student was born in the cutoff months of a Dragon year. The results using this adjusted Dragon dummy are reported in columns (4) to (6) in Table 5. The inference does not change.

Overall, the results in Table 5 show that, controlling for a number of covariates, having been born in a Dragon year is associated with an increase in the university exam score by 9 to 10 points. This result is consistent with the raw differences depicted by Figure 4. 


\section{Analysis of Middle School Students}

The regressions reported in Table 6 analyze the impact of having been born in a Dragon year on test scores of middle school students. The descriptive statistics used in these regressions are provided in Table 3. The regressions use 13,309 middle school students who are in the $7^{\text {th }}$ or $9^{\text {th }}$ grade in 438 classrooms from 112 schools. In this sample, those born in 2000 have the zodiac of the Dragon. Figure 5 presents the timeline of the Gregorian calendar, its overlap with the relevant zodiacs and the school years.

The results in Table 6 display three regressions, where the dependent variables are students' midterm test scores in Mathematics, Chinese and English. In addition to student characteristics, the regressions also control for parent attributes and classroom fixed effects. Standard errors are clustered at the classroom level. The coefficients reported in Table 6 reveal that parent education has a significant impact on test scores in all three subjects. Female students score higher, and age-for-grade has a negative impact on midterm scores.

Column (1) of Table 6 shows that the students born in a Dragon year score higher in Mathematics, although the estimated impact is not statistically different from zero. Columns (2) and (3) indicates that Dragon children score higher in both Chinese and English mid-term exams and that these magnitudes are statistically different from zero. Specifically, being born in the Dragon year leads to around 0.04 and 0.03 of a standard deviation increase in the test scores in Chinese and English, respectively. The magnitude of the effect is as large as peer effect and teacher's gender effect found in some previous studies (eg. Lavy et al., 2012; Hanushek et al., 2009; Brunello et al., 2010; Lim and Meer, 2017). Alternatively, we present the results obtained utilizing the adjusted Dragon dummy in the Appendix Table A2. The results are very similar to the baseline results. 
Regressions in Table 6 control for parents' education, parents' job type (white collar occupations) and an indicator for high family income. Therefore, the impact of the Dragon zodiac on test scores are not driven by parents' education or income. It could, however, be the case that Dragon children have higher self-esteem than other kids, and that higher selfesteem can have a positive impact on test scores. The detail of the data set allows us to test this hypothesis. Specifically, students were asked to evaluate their own attributes ranging from beliefs in their mental ability to their career ambitions.

Regressions reported in Table 7 explain students' self-evaluations on six dimensions. For example, the dependent variable in column (1) of Table 7 is a dummy variable to indicate if the student believes that she/he can articulate his/her thoughts clearly. The dependent variable of the model in column (2) is an indicator on whether the student believes that he/she is a fast thinker. Other self-evaluated attributes are whether the student believes that she/he is a quick thinker, whether she/he wants to go to college, whether she/she wants to be a leader or officer in national/government institutions, a scientist, an engineer or an executive in a company and whether he has faith in this/her own future. The descriptive statistics of these variables are provided in Table 3.

The results of Table 7 show that the coefficient of the Dragon dummy is small in each regression and never significantly different from zero. This indicates that having been born in a Dragon year has no impact on various aspects of self-esteem. Thus, self-esteem cannot be the reason to explain the impact of the Dragon dummy on test scores, reported in Table 6. 


\section{Are Dragon Parents Different?}

As mentioned earlier in the paper, it can be argued that parents of Dragon children may be different from other parents. For example, they may be more educated, or they

may have more income. If such attributes of the parents make them more likely to time their birth and make it more likely for them to have Dragon child, and if these attributes also impact child outcomes, then it would be the influence of these factors that impact child's education and test scores. To eliminate such confounding in the regressions we control for all available parent attributes, including income, occupation and education.

To formally investigate whether Dragon parents and other parents differ from each other in observable dimensions, we run parent attributes on a dummy to indicate if their child was born in Dragon year. We do this in all data sets used in the paper. The results are reported in Table 8. Panel A displays the results from the CGSS sample, which shows that the probability of the father having at least a bachelor's degree is not different between the father of Dragon children and other fathers. The coefficient of the Dragon dummy is 0.005 and highly insignificant. The same is true about mothers' education. Mothers of Dragon children are no more likely to have a college education or higher. Panels B and C of Table 8 demonstrate the same picture in other data sets. In no case do we see a difference between the parents of Dragon children and other parents regarding their education, income or the probability of having a white-collar occupation. 


\section{It is all about Parents' Beliefs and Investment in Children}

The middle school data set also includes questions about how parents perceive their kids' future and how they expect their children's future to look like. The questions that were asked of parents include whether parents believe their child will obtain at least a high school diploma, whether they believe that their child will obtain at least a bachelor's degree, whether they expect the child to become a leader or officer in national/government institutions, a scientist, an engineer or an executive in a company, and whether they have faith in their child's future. ${ }^{25}$ Table 9 presents the results of these regressions. The models include attributes of the children, as well as parent characteristics including parent education and family income status. In all cases the Dragon dummy is positive, and in four of the five models it is highly significant. This indicates that all else the same, parents have higher expectations of their child if their child is born in the year of the Dragon. Because we investigate multiple outcomes in Table 9 that gauge different but related parent expectations, we adjust the p-values of the Dragon dummy for multiple hypothesis testing (Newson 2010, Benjamini and Yekutieli 2001). The adjusted $p$-values, presented in the footnote of Table 9, reveal that the inference is not altered.

Parents' high expectations about their child’s current success in school as well as his/her future success can translate into devoting resources to the child. For example, parents may spend more time consulting teachers about their child, or they may be less likely to require their children to help with the chores around the house. Furthermore, if

\footnotetext{
${ }^{25}$ No parents expect their children to get a college diploma without getting a high school diploma. There 64 parents in the data who expect their children's education to stop before regular high school but still wish their children to find a job as a leader or employer in government or national institutions.
} 
parents' expectations about their child's future are related to the investment made in the child (the effort and the resources parents spend on their child), parent expectations would be positively related to the child's test scores. To investigate this hypothesis, we modified the midterm test score regressions (displayed in Table 6) by including the variables that gauge parent expectations. Any change in the estimated value of the coefficient of the Dragon dummy in these regressions reveal information about the mechanism through which the Dragon dummy impact test scores. Specifically, given that parents of Dragon children have higher expectations of their children (see Table 9), to the extent that the Dragon dummy acts as a proxy for these expectations, including both the Dragon dummy and parent expectations as explanatory variables to the model to explain test scores should provide a coefficient of the dragon dummy that is smaller in magnitude in comparison to the models that excludes parent expectations.

We add parents' expectations into the models reported in Table 6. The new results are reported in Table 10. Compared to those reported in Table 6, the coefficients of the Dragon dummy variable are about half as large in the Chinese midterm score regression (column 2), 80 percent smaller in English midterm score regression (column 3) and it becomes negative in the Math score regression (column 1), and they are not different from zero in any three columns. This indicates that after controlling for parents' expectations, the Dragon zodiac no longer explains higher test scores of the Dragon kids. On the other hand, all five variables measuring parent expectations have positive and significant coefficients.

It can be argued that higher test scores of the student prompt his/parents to raise their expectations; i.e. test scores may shape parent expectations. To investigate the validity of such reverse causality between students' test scores and parental expectations, we replicate 
the analyses in Table 6 and Table 10 by employing data from the 2014-2015 wave of CEPS. The CEPS conducted a follow-up survey one year later for all students who were in the $7^{\text {th }}$ grade in the previous wave (2013-2014). Thus, we regress $8^{\text {th }}$ grade test scores on parent expectation in the $7^{\text {th }}$ grade. Because the $8^{\text {th }}$ grade test scores cannot impact parents' expectations formed one year earlier, any potential baise due to reverse causality is not relevant in this specification. The results, reported in the Appendix Table A3, are consistent with those reported in Tables 6 and 10. Thus, they confirm the finding that parental expectations is the channel through which the "Dragon effect" works. ${ }^{26}$

Table 11 presents the regression results that test whether parents of Dragon children in fact invest more in their children in comparison to other parents. The results reported in column (1) of Table 11 suggest that parents of Dragon kids are 1.4 percentage points more likely to take the initiative to actively contact their child's teachers 5 or more times in the current semester in comparison to other parents. The results in columns (2) and (3) indicate that parents of Dragon kids have a higher propensity to enroll their children in kindergarten and that they give more pocket money to their children. The dependent variables in columns (4) and (5) measure whether the child often spends time on house chores. The estimates suggest that Dragon kids are less likely to help parents on housework. Thus, the results of Table 11 reveal that parents of Dragon children invest more time and money in their offspring in comparison to other parents.

\footnotetext{
${ }^{26}$ Students who were previously in the $9^{\text {th }}$ grade were not surveyed in the follow-up wave of the CEPS conducted in 2014-2015.
} 


\section{Child Height}

Parents may also invest in their children in terms of nutrition. The data set contains no information about the food intake of children but there is information on the height of middle school students. Given the evidence that height in adolescence is strongly correlated with nutrition intake during childhood (see Case and Paxson 2008 and the literature they cite) we ran regressions of height of middle school students on the Dragon dummy, controlling for the same set of explanatory variables as before, including the age of the student. The results are displayed in Table 12. Column (1) shows that female students are about $6.4 \mathrm{~cm}$ shorter than males, but that being a female Dragon child has a positive impact on height. Specifically, having been born in the year of the Dragon helps reduce the female height gap by 2.7 centimeters. Columns (2) and (3) present the results by students' location of residence. The average height of rural students is $160.8 \mathrm{~cm}$, whereas students in urban areas are $163.2 \mathrm{~cm}$ tall on average. Columns (2) and (3) reveal that the impact on height of being a female dragon child is larger in rural areas (3.3 cm vs. $1.9 \mathrm{~cm})$, which is confirmed by the results presented in column (4). Thus, the results in Table 12 indicate that even though girls are six centimeters shorter than boys this height disadvantage is mitigated by having a Dragon zodiac. Specifically, if a female middle school student is born in the year of the Dragon she is $2.7 \mathrm{~cm}$ taller than another female student of the same age. This is consistent with the hypothesis of allocation of additional nutritional resources to girls if they are born in the year of the Dragon. That this effect is larger in rural areas is also consistent with the hypothesis that food and nutrition may be driving this finding because investment in children in terms of food and nutrition should be more prevalent in rural, as opposed to urban areas. 


\section{Analyses of Narrow Birthday Windows}

As discussed in Section IV, we are able to implement a sharp RD approach, taking advantage of the information on the exact birthdates of the individuals in the CGSS sample. We tested the discontinuity of the running variable following Cattaneo et al. (2018). ${ }^{27}$ The results are presented in Figure 6. The figure displays continuity of the running variable at the cutoff dates of the Dragon year. ${ }^{28}$ We implement two methods to test for the smoothness of the covariates used in the analyses. The results are displayed in Figure 7 and Table A4. In Figure 7 we show the fitted value of the outcome predicted by all the covariates utilized in the main analyses. The fitted values are averaged by every 30 days. The figure shows that the fitted values are continuous around the cutoff point. Alternatively, we present the local linear regression estimates of all the covariates in the Appendix Table A4. No estimate is different from zero. Taken together, these results indicate that the assumptions for implementing a RD approach are fulfilled.

Figure 8 displays the average probability of having at least a college degree of Dragons in comparison to those born earlier or later (i.e. Rabbits and Snakes). The outcome is averaged by 30-day bins, i.e. each dot represents the average propensity for holding a bachelor's or higher degree for individuals born within a given month. Dragons are presented on the right side of the cutoff and to the left of the cutoff are those who are born in both the Rabbit and the Snake years. The figure displays a sharp and clear jump in the

\footnotetext{
${ }^{27}$ This test is an improved version of the McCrary (2008). The advantage of this procedure is that it does not require pre-screen of the data, and it auto-determines the bandwidth. A recent application is in Cabrera and Webbink (forthcoming).

${ }^{28}$ Consistent with the figure, we cannot reject the continuity of the running variable at the cutoff point with a $p$-value of 0.591 .
} 
level of educational attainment between the Dragon cohort and the adjacent cohorts. The RD estimates obtained using the optimal bandwidths are reported in the first column of Table 13. The coefficient indicates that those in the Dragon cohort are 9 percentage points more likely to receive a bachelor's degree or higher. This result is consistent with the baseline results using the CGSS data (Table 4). As a robustness check we repeat the analysis using $0.85,1.25,1.5$ and 2 times of the optimal bandwidths, reported in columns (2)-(4) of Table 13. The results do not change. We also employ a model using the first or second order polynomials as further robustness checks. The results, reported in the Appendix Table A5, are very similar to those obtained from the non-parametric model. Finally, we estimate the models using a triangular kernel with different bandwidths. As displayed in panel B of Table A5, the results remain the same.

Ninety-five percent of the middle school students who are analyzed in regressions, reported in Tables 6-11, were born between 1998 and 2001. In this section we focus on students who were born in narrower time intervals. Because the Dragon year covered the period from February 5, 2000 to January 23, 2001 (see Figure 5), we focus on $7^{\text {th }}$ grade students who were born during the last full month of the Dragon year (December 2000) or during the first full month of year of the Snake (February 2001). This sample contains 847 students, with Dragon kids constituting 55 percent of the sample. Under the assumption that some parents were trying to give birth to a Dragon baby, these two groups of students consist of those who barely made the cutoff of the Dragon year and those who missed being born in the Dragon year by a few weeks. We drop those who are born in January 2001 because in this middle school data set, although we know the birth month of the students, don't know their birth day. Figures 9, 10, and 11 display the average test scores of these 
two groups of students, net of the impact of co-variates. Panel A of Table 14 presents the regressions of test scores in this narrow sample. ${ }^{29}$ The results are consistent with those reported in Table 6. Having been born in a Dragon year, as opposed to the year of the Snake, is associated with higher test scores. Panel B of Table 14 shows that doing the same exercise for the same group of students but controlling for parents' expectations (as was done in Table 10) cuts the magnitude of the Dragon dummy in half in English and Chinese test score regressions and turns the coefficient of the Dragon dummy to negative in the math regression; and none of these effects is different from zero. This is the same result reported in Table 10. In summary, accounting for parent expectations eliminates the Dragon impact in this narrow sample as it was the case in the large sample of middle school students.

We repeat the exercise of focusing on narrow samples in the BCSS sample that consists of college students. Recall that this sample contains the Dragon cohort of 1988, which spanned February 17, 1988 to February 5, 1989. Thus, we extract the students born in the beginning and at the end of the Dragon year (those born in March 1988 and in January 1989) as well as those just missed the Dragon year (those born a bit early, in January 1988, before the Dragon year started, and those who are born and a bit late in March 1989 after the Dragon year ended). Average university entrance exam scores of these groups are displayed in Figure 12, and Panel C of Table 14 shows that 137 Dragon students of this sample of 250 (the rest being Rabbit or Snake), have higher university entrance exam scores, controlling for other covariates as was done in the regressions of Table 5. In

29 The test scores are purged of all other determinants shown in Table 6 by first regression the scores on all covariates other than the Dragon dummy in the whole sample and then running the residuals on the Dragon dummy in the sample of 847 students. 
summary, the analyses in this section reveal that the results presented in the paper are robust to doing the same analyses in narrower samples which contain people with Dragon zodiac and those who are born in adjacent months.

\section{Do Dragon Parents Invest in their Kids because of the Fear of Competition?}

As Table 11 demonstrates, parents of middle school Dragon children invest more heavily in their kids in comparison to other parents. The assumption behind this finding is that the parents of Dragon children believe that their children are inherently more productive as suggested by the superstition. Thus, an investment in these kids would produce higher returns in comparison to investment in other kids (by other parents). In other words, Dragon parents would invest more heavily in their kids as opposed to other parents because the return of their investment is higher. It can be argued, however, that parents do not believe that Dragon children are superior. That is, they prefer their kids to be born in a Dragon year for some other reason, but they don't actually think that Dragon kids are destined for greatness. ${ }^{30}$ Yet, everyone recognizes that the Dragon cohorts are larger and therefore these Dragon children would be at a disadvantage unless additional resources are allocated to them to compensate for the intensity of competition they would face due to the large cohort size. In this scenario, Dragon parents invest in their children to counteract the drawback of their kids being a member or a large cohort. To investigate the validity of this conjecture, we focus exclusively on $7^{\text {th }}$ grade students who are classmates. This subsample of middle school students consists of only those who were born in a Dragon year or in a Snake year. This cohort of the $7^{\text {th }}$ graders is large because of the

\footnotetext{
${ }^{30}$ As discussed earlier, we show in the paper that Dragon parents have higher expectations of their children in comparison to other parents, refuting this claim.
} 
Dragon children; and the parents of the Snake children should also be aware of this fact. Thus, $7^{\text {th }}$ grade parents whose children were born in the year of the Snake should be worried about the increased competition due to the large cohort size generated by the Dragon kids in the $7^{\text {th }}$ grade, and these Snake parents are expected to invest in their kids as heavily as do the parents of the "competing” Dragon kids. This argument suggests that there should not be a significant difference between these two groups of parents in terms of investment in their offspring.

Appendix Table A6 presents the summary results of the analyses done in this sample of $7^{\text {th }}$ graders. Specifically, analyzing the test scores of the $7^{\text {th }}$ graders who are in the same classrooms, Panel A of Table A6 (which is the counterpart to Table 6) shows that Dragon children receive higher test scores in comparison to Snake children.

It could be argued that the Dragon students outperform the students who are born in the year of the Snake (although both types are in the same classroom) because Dragon students in the $7^{\text {th }}$ grade are a few months older than their classmates who are Snakes. If this were the case, however, one would observe the same age impact on test scores among other cohorts as well. Thus, we analyze the sample of $9^{\text {th }}$ grade students which consists of only the Tiger and Rabbit cohorts. We regress the test scores on a dummy that indicates a student being born in the Tiger year. Although all of these students in this sample are in the $9^{\text {th }}$ grade, those who were born in the year of the Tiger are a few months older than those who are Rabbits (see Figure 1). As shown in the Appendix Table A7, however, the Tiger dummy is not different from zero, indicating that test scores are not different between classmates who are either Rabbit or Tiger. This suggests that the results reported in Table 
A6 are not attributable to Dragon students being a few months older than their classmates in the $7^{\text {th }}$ grade.

Similarly, we examine if the parents of the Tiger students have higher expectations than the parents of the Rabbit students. As shown in Table A8, we again find no difference in parental expectations between the Tigers and Rabbits.

Consistent with Table 7, Panel B of Table A6 shows that $7^{\text {th }}$ grade Dragon children are not different from $7^{\text {th }}$ grade Snake children in terms of their self-esteem, and expectations for their own future. Panel C of Table A6, which is the counterpart of Table 9, demonstrates that parents of Dragon children have higher expectations of their children in comparison to the parents of Snake children who are classmates of Dragon kids. The point estimates and statistical significance between Tables 9 and Table A6-Panel C are almost identical despite the reduction in the sample size by half in the latter table.

Panel D of Table A6 reveals that holding constant parent expectations eliminations the "Dragon" effect from the test score regressions of the $7^{\text {th }}$ graders (as was the case in the big sample of $7^{\text {th }}$ and $9^{\text {th }}$ graders - see Table 10). Finally, panel E of Table A6 shows that parents of Dragon kids in $7^{\text {th }}$ grade classrooms invest more heavily in their kids in comparison to parents of the Snake kids in the same classrooms. This finding is inconsistent with the hypothesis that Dragon parents invest more in their kids because they want to compensate for the large cohort size in which their kids operate. This is because, the same argument applies to the Snake parents: the kids of the Snake parents too face intensified competition because of the large cohort size, inflated by Dragon kids. But panel E of Table A6 shows that Dragon parents invest more in their kids, and that the point estimates are very similar to those obtained from the big sample (of $7^{\text {th }}$ and $9^{\text {th }}$ grades) displayed in Table 
11. Unless one is prepared to argue that parents of Snake children do not care about the success of their offspring, this finding refutes the conjecture that Dragon parents invest in their kids because they are worried about the competition with a large number of students in the cohort.

\section{Conclusion}

In Chinese culture those who are born in a Dragon year are believed to be destined for good fortune and greatness. Because there is no biological reason for people who are born in a certain time period be more successful economically in comparison to those who are born in adjacent time periods, it is surprising that this superstition has persisted for many centuries.

If the cohort size of Dragon children is larger, this would intensify competition among children of that cohort in terms of educational resources. For example, class sizes in schools would be larger for kids born in Dragon years, which may reduce the quality of education they receive. Similarly, competition for a slot in a high-quality college could be more intense. If this is the case, and if children born in a Dragon year have worse educational outcomes in comparison to their peers who are similar in age and in other attributes, this would beg the question of how this particular belief about Dragon children being destined for good fortune greatness could persist.

Using three recently collected micro data sets from China we show that those born in a Dragon year have better, rather than worse, educational outcomes in comparison to similar individuals who are of the same age, or who are very similar in age, but who have different zodiac year designations. Those born in a Dragon year are more likely to have a 
college education, and they obtain higher scores at the university entrance exam. Similarly, Chinese middle school students have higher test scores if they are born in Dragon year. We show that these results are not because of family background, self-esteem or student's expectations about their own future. We find, however, that the "Dragon" effect on test scores is eliminated when we account for parents' expectations about their children's educational and professional success.

In all three data sets analyzed we find that parents of Dragon children are not different from other parents in terms of education of occupation, We find, however, that parents of Dragon children have higher expectations for their children's education success and their professional future in comparison to other parents, and that Dragon parents invest more heavily in their children in terms of time and money (the amount of pocket money parents give to the child, how many times parents talk to the child's teachers during the semester, whether the child is protected from doing chores at home, and so on). We also find that although female middle school students are about six centimeters shorter than male students of the same age, this height disadvantage is cut by about half by having a Dragon zodiac for females, and that this effect is larger in rural areas. This may suggest that parents may be allocating more food and nutrition to female Dragon children, especially in rural (and poorer) areas as a form of investment.

An alternative hypothesis that may be consistent with these results is that some parents care much more about their children's success, that these parents have high expectations of their children and that they invest heavily in their children. These parents are not superstitious but they nevertheless time their pregnancy so that their children are born in the year of the Dragon. In this scenario children are born in a Dragon year not because of 
parents' superstition but because their parents are investor and planners, (including planning the timing of the birth in a Dragon year). But, if parents time their pregnancy so that their children are born in the year of the Dragon, this is superstitious behavior by definition. Furthermore, if this is the dominant behavior of parents, their expectations of children's achievements and the outcomes of their children should be similar in a narrow window on both sides of Dragon zodiac cut-off. That is, parents who make slight timing errors in pregnancy should be similar to parents who time their pregnancy accurately. The same should be true for the children of both types of parents. Analyzing narrow windows around Dragon year cutoff dates we show that this is not the case. There are significant differences in parent expectations and student outcomes between those who are born in the last month of the Dragon year and those who are born just one month later. Similarly, using a sharp Regression Discontinuity Design around Dragon year cutoff dates we show that the probability of having at least a college degree is higher for the Dragon children.

It is possible that Dragon parents who believe in the superstition not only invest in their kids in the ways we measure in this paper (e.g. talking to the classroom teachers more frequently in the middle school, protecting their kids from doing house chores, etc.), but they also invest in other ways, such as by buying books and computers for their children, hiring tutors for them, and so on. ${ }^{31}$ These potential additional investment avenues that may have also been utilized by parents do not alter the message of this paper: Even though

\footnotetext{
31 Dragon parent could have invested in their kids even before they were born, by consuming more health inputs during pregnancy (nutritious foods, prenatal care, etc.). While we cannot test whether birth weight is different between Dragon children and others, research indicates that the impact of birth weight on test scores and on educational attainment is modest (Figlio et al. 2014,Royer 2009, Rosenzweig and Zhang (2013). Furthermore, our middle school data set, which contains information on cognitive test scores, shows that there is no difference between Dragon kids and other kids in cognition, measured by this test.
} 
children born in a Dragon year are no different from other children in the dimensions we observe in our data, ranging from family background to self-esteem, and expectations and aspirations about their future, Dragon students are more successful in school. This is because the parents of Dragon children have higher expectations of their children and they invest in their children more intensely. In the end, these higher expectations yield better educational outcomes. Put differently, these expectations and the ensuing investment create this self-fulfilling prophecy. 
Figure 1

The Order of Twelve Chinese Zodiacs

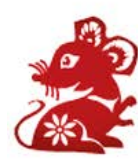

Rat

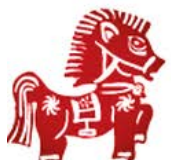

Horse

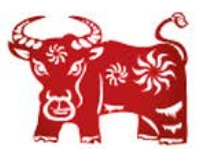

$\mathrm{Ox}$

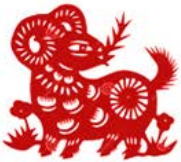

Sheep

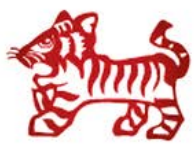

Tiger

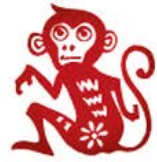

Monkey

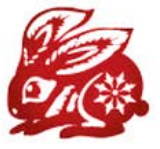

Rabbit

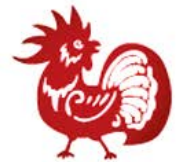

Rooster

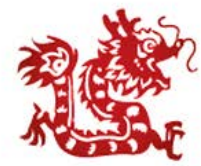

Dragon

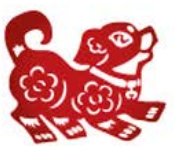

Dog

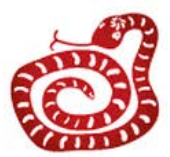

Snake

Figure 2

The Numbers of Live Births in China 1995-2014.

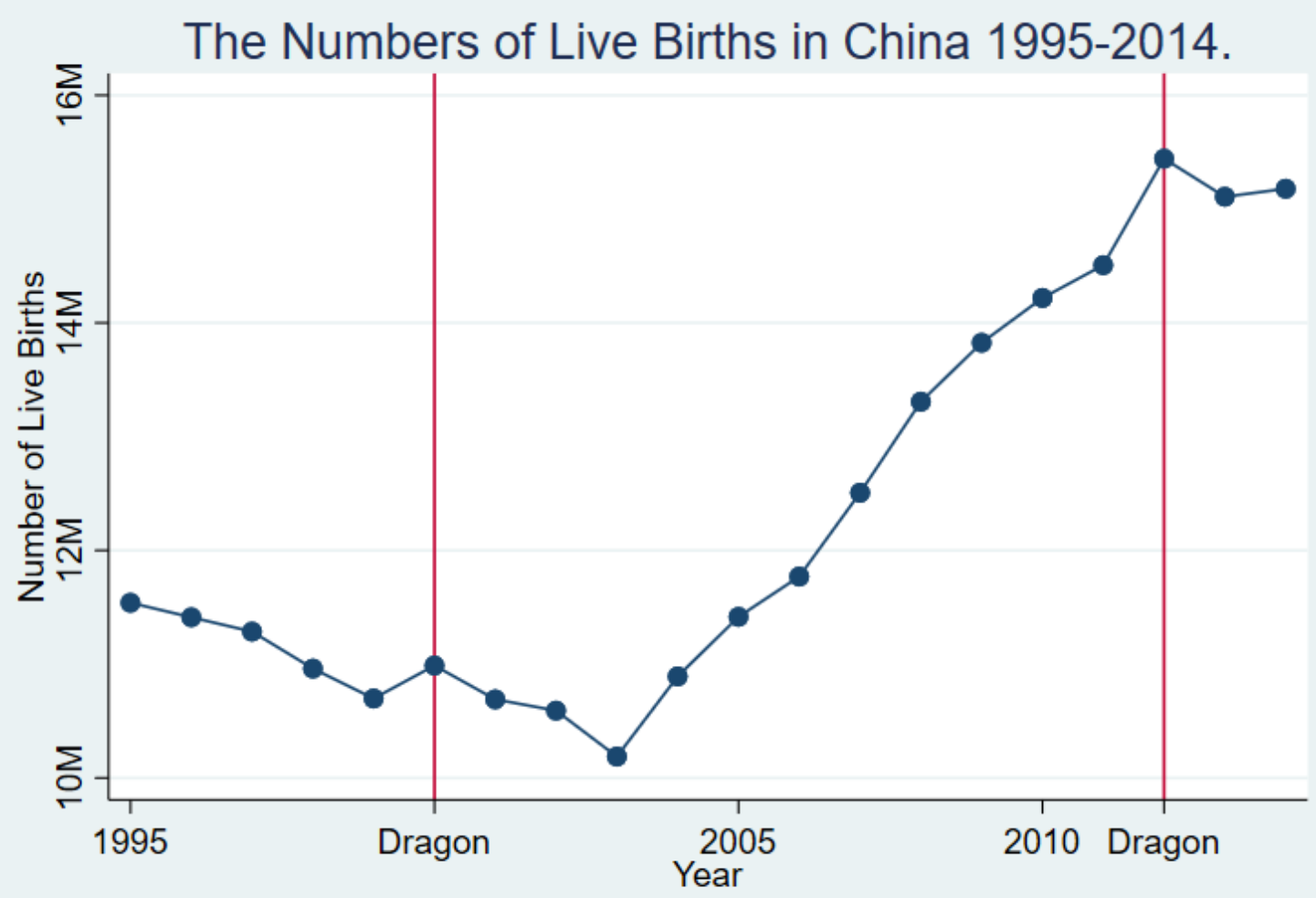

The data are from China Health Statistical Yearbook 2015 
Figure 3

Proportion of Individuals with a Bachelor's Degree or Higher by Their Zodiacs

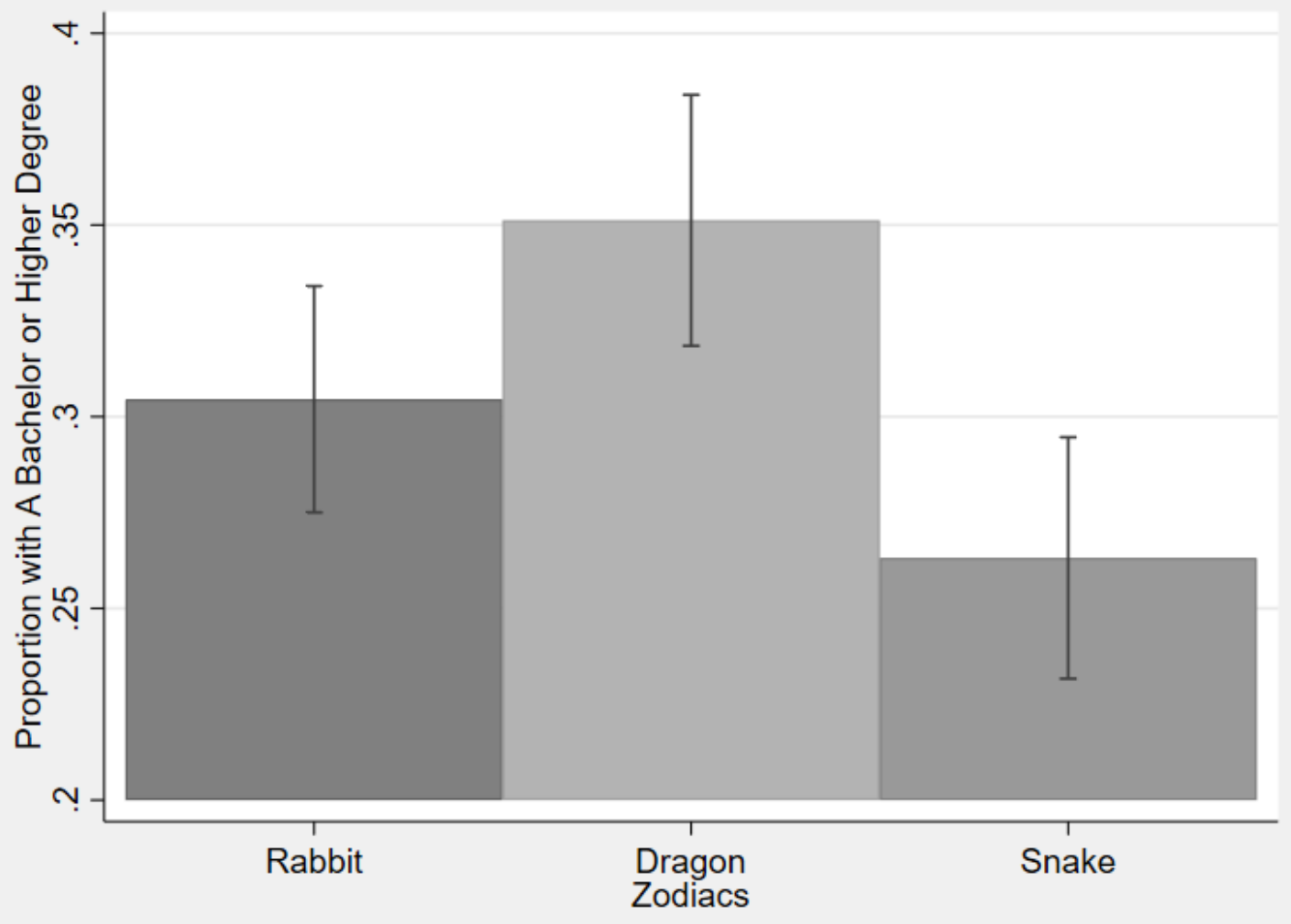

Figure 4

National College Entrance Exam Scores and Zodiacs

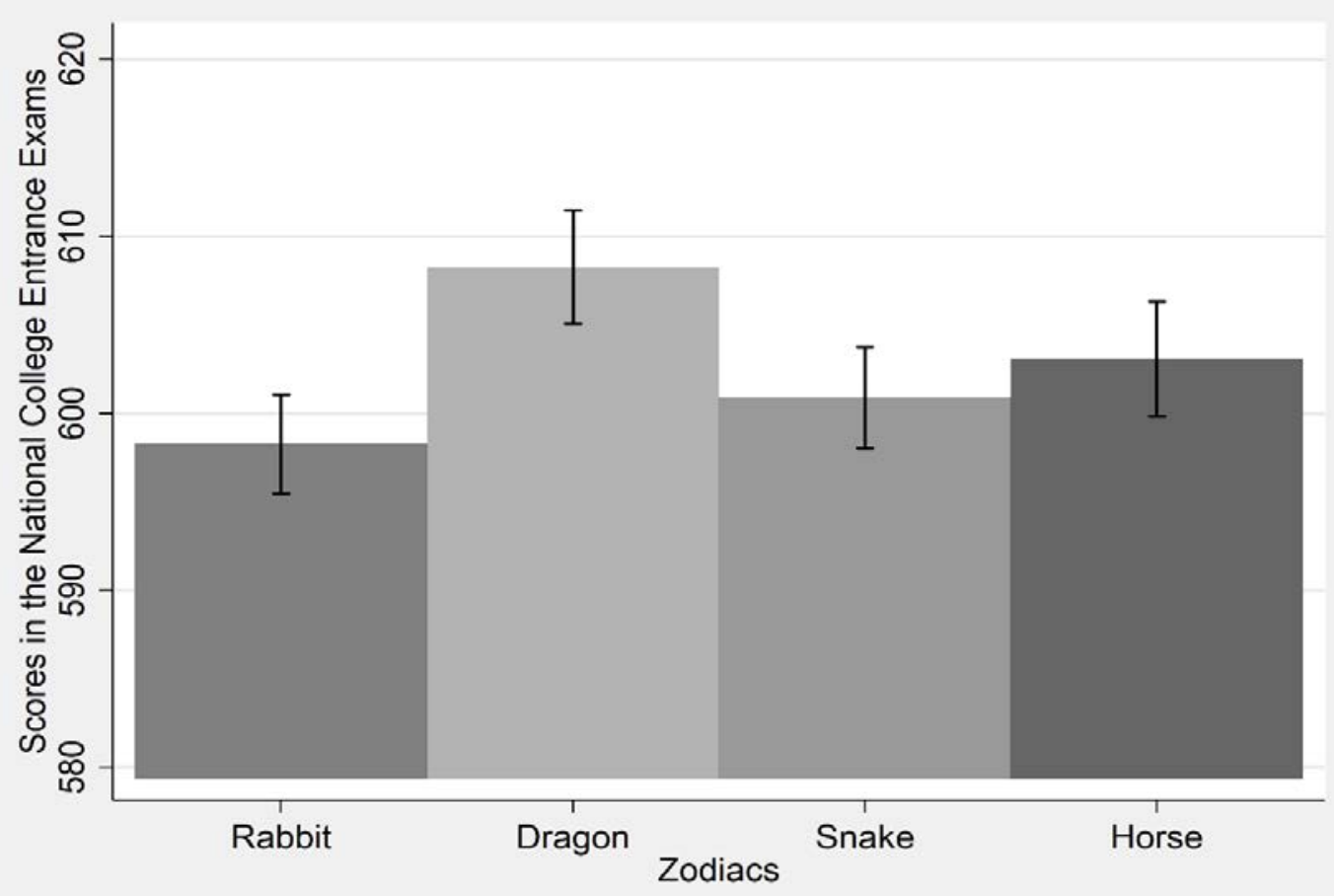


Figure 5

The Overlap between the Chinese Lunar Calendars, the Cycle of Zodiacs and Academic Years

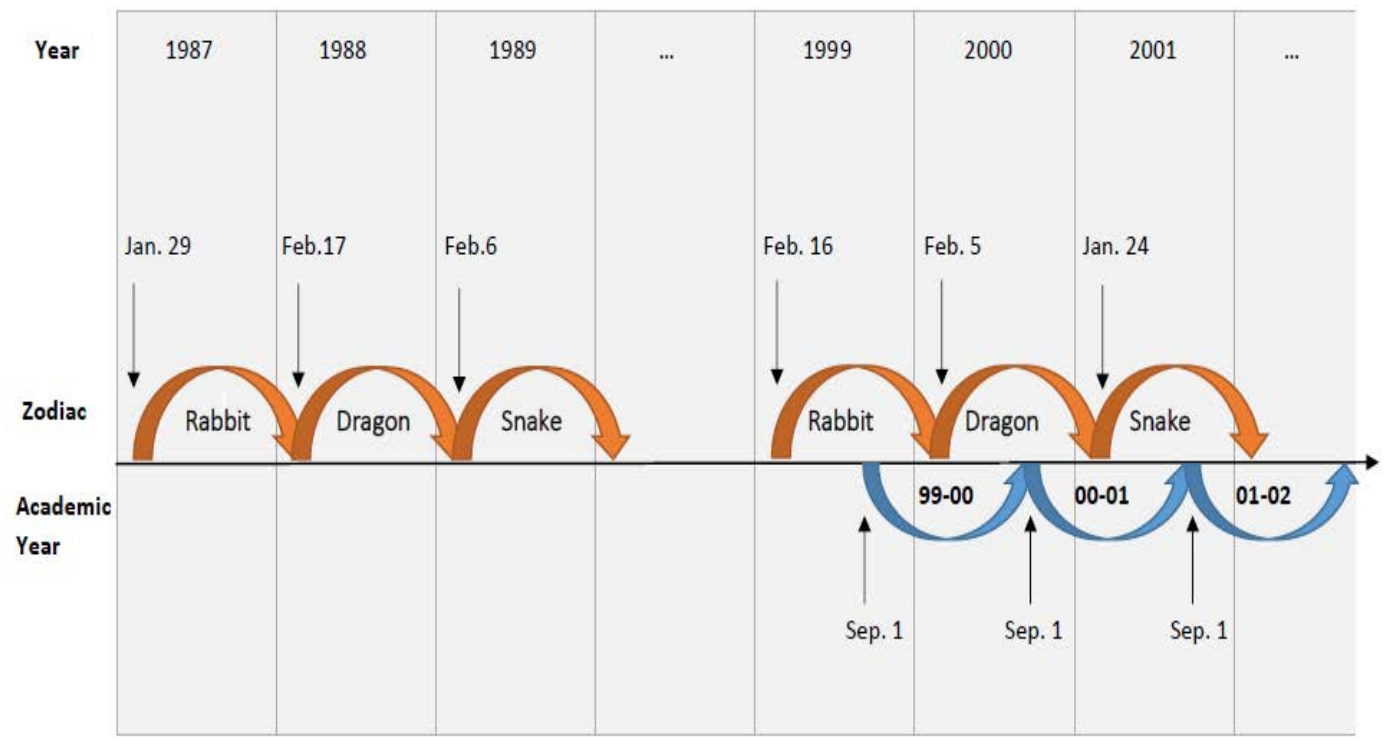

Figure 6

\section{Density Discontinuity Test of the Running Variable (Birthday)}

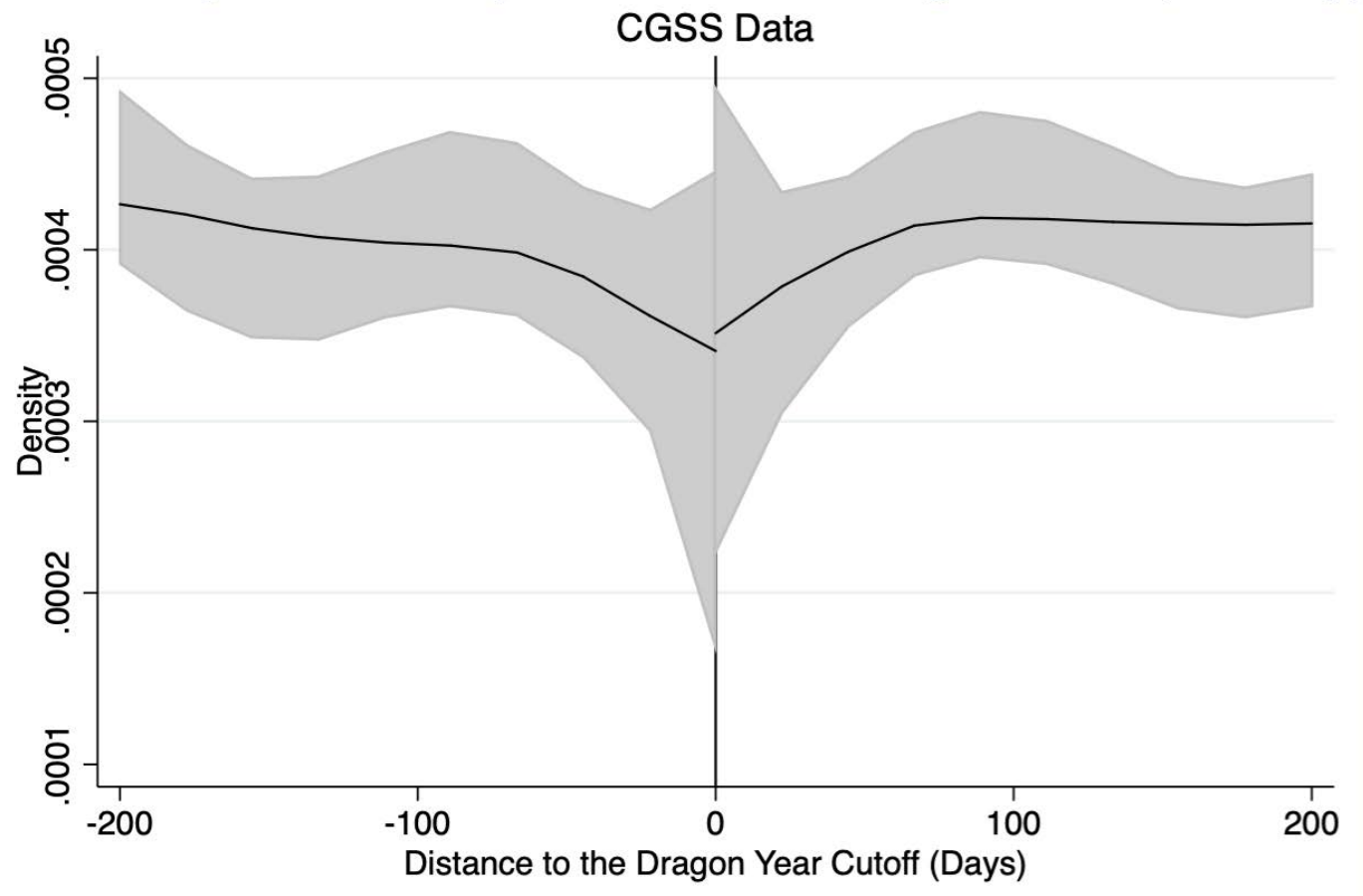


Figure 7

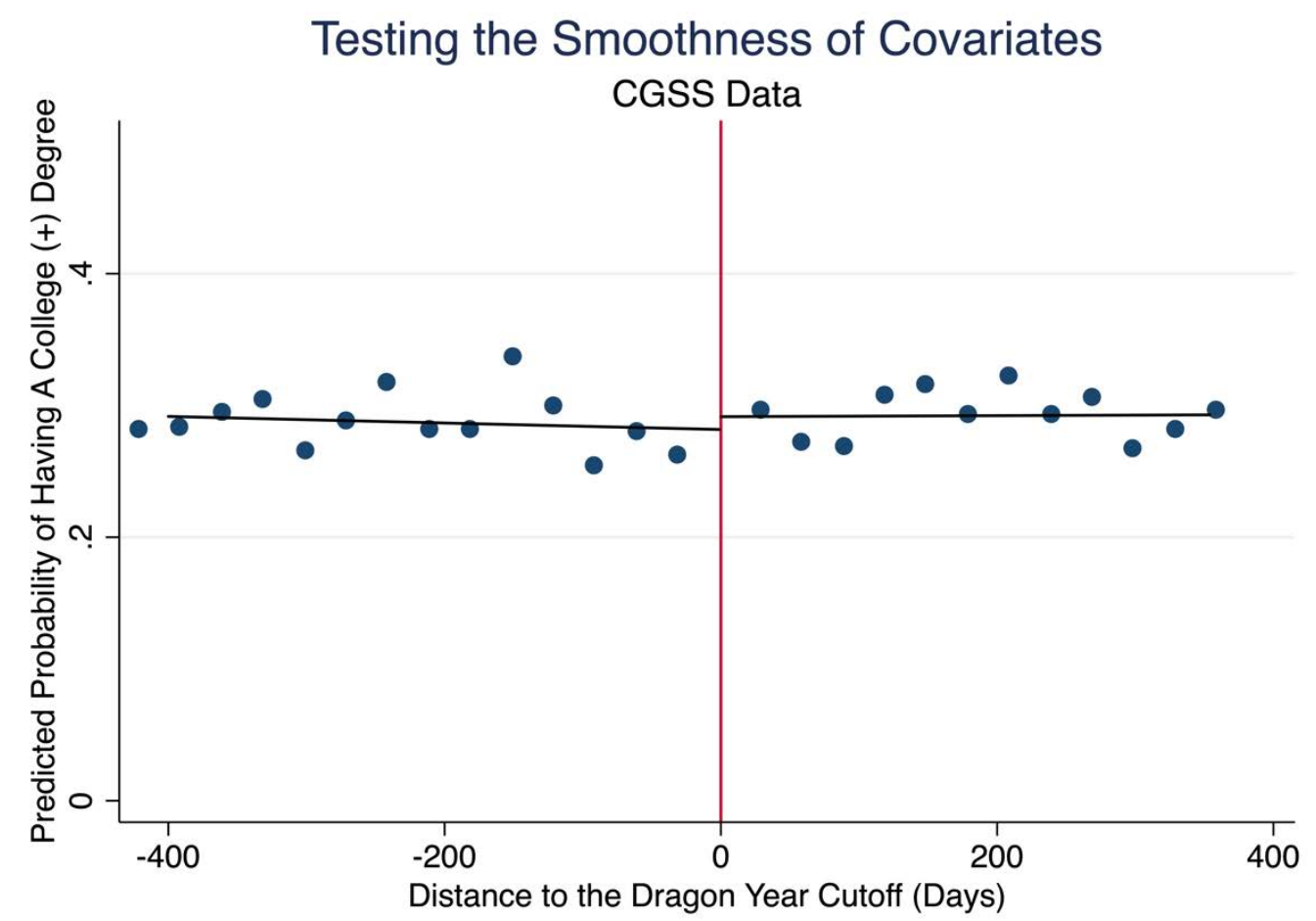

Figure 8

Discontinuity of Education at the Dragon Year Cutoff

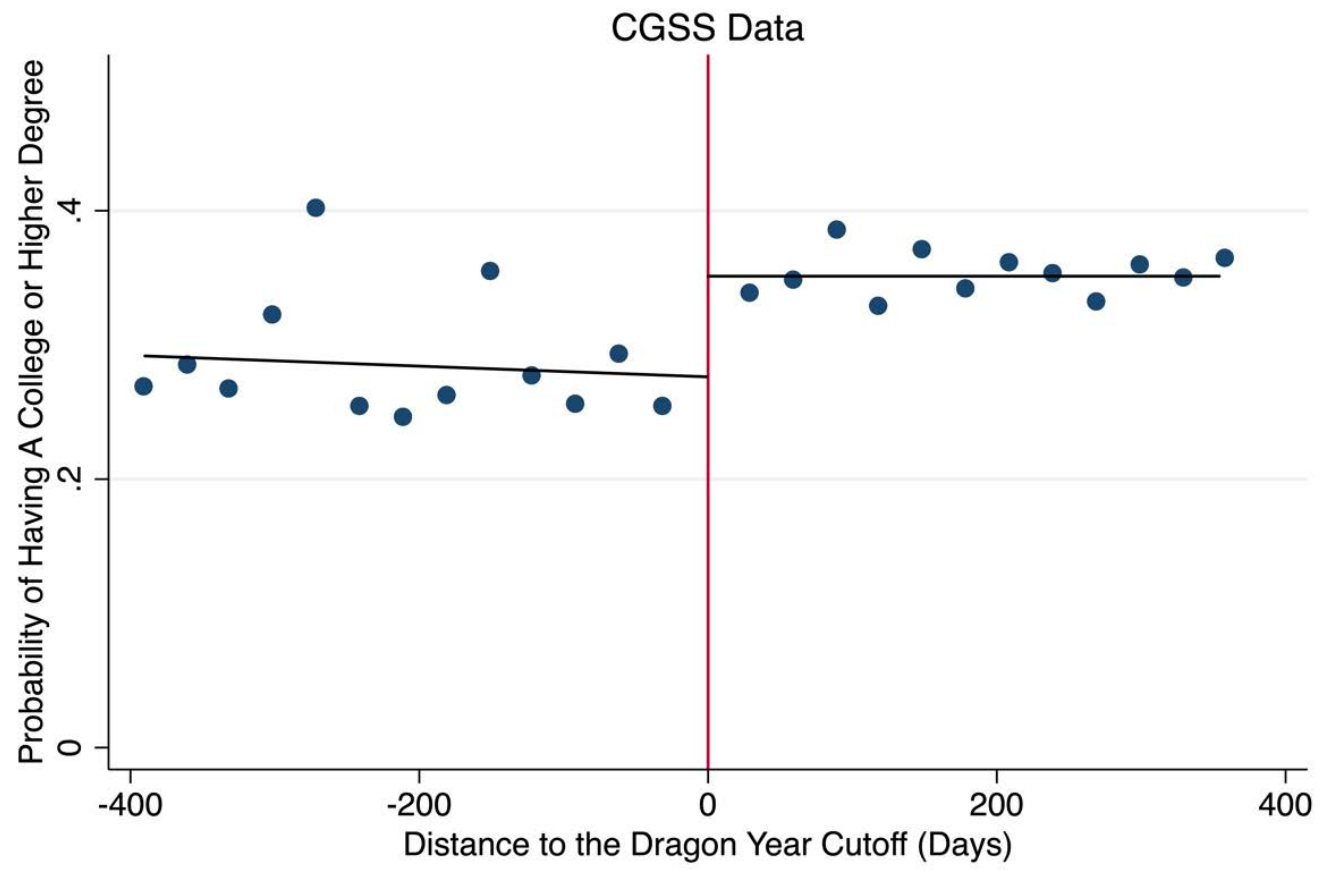


Figure 9

Middle School Students' Zodiacs and Math Test Scores (Narrow Sample)

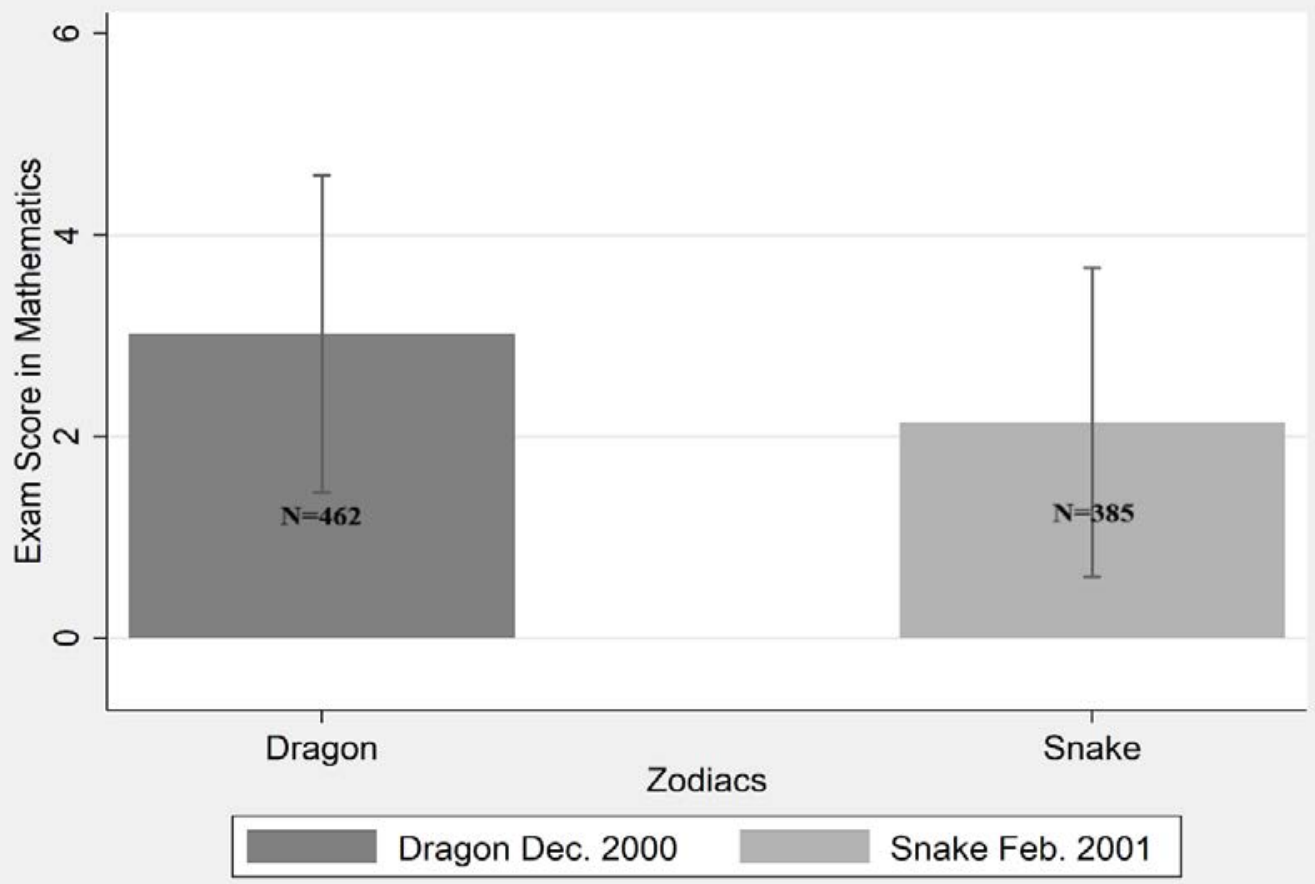

Note: The y-axis presents the residuals from regressing Math test scores on the covariates.

Figure 10

Middle School Students' Zodiacs and Chinese Test Scores (Narrow Sample)

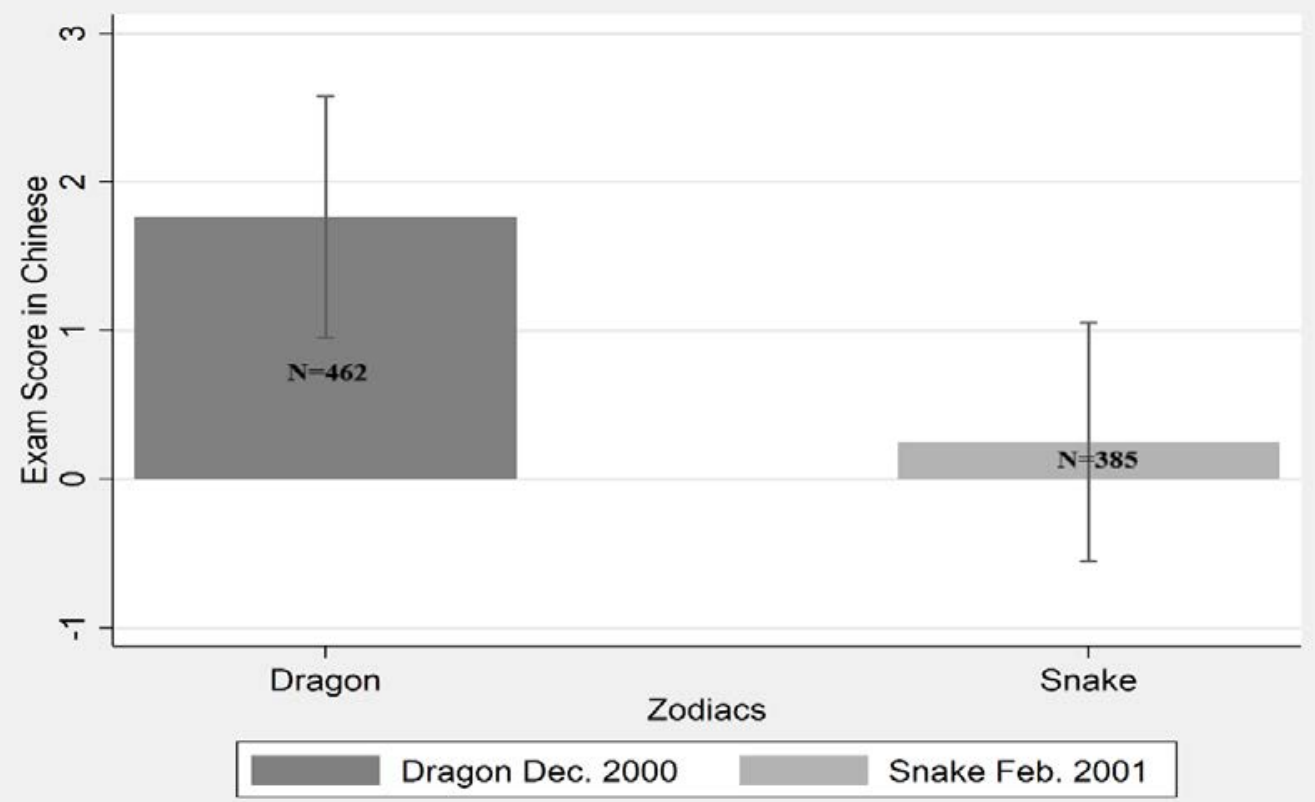

Note: The $y$-axis presents the residuals from regressing Chinese test scores on the covariates. 
Figure 11

Middle School Students’ Zodiacs and English Test Scores (Narrow Sample)

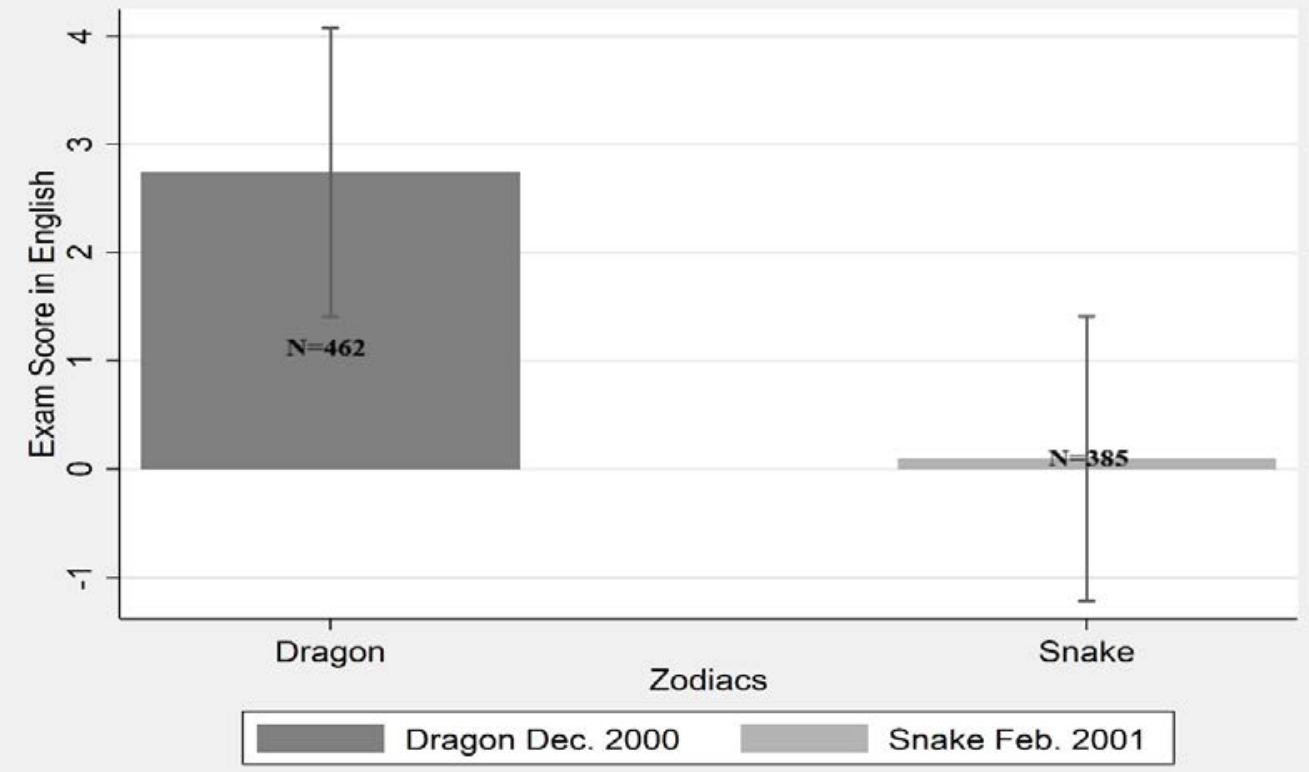

Note: The y-axis presents the residuals from regressing English test scores on the covariates.

Figure 12

National College Entrance Exam Scores and Zodiacs (Narrow Sample)

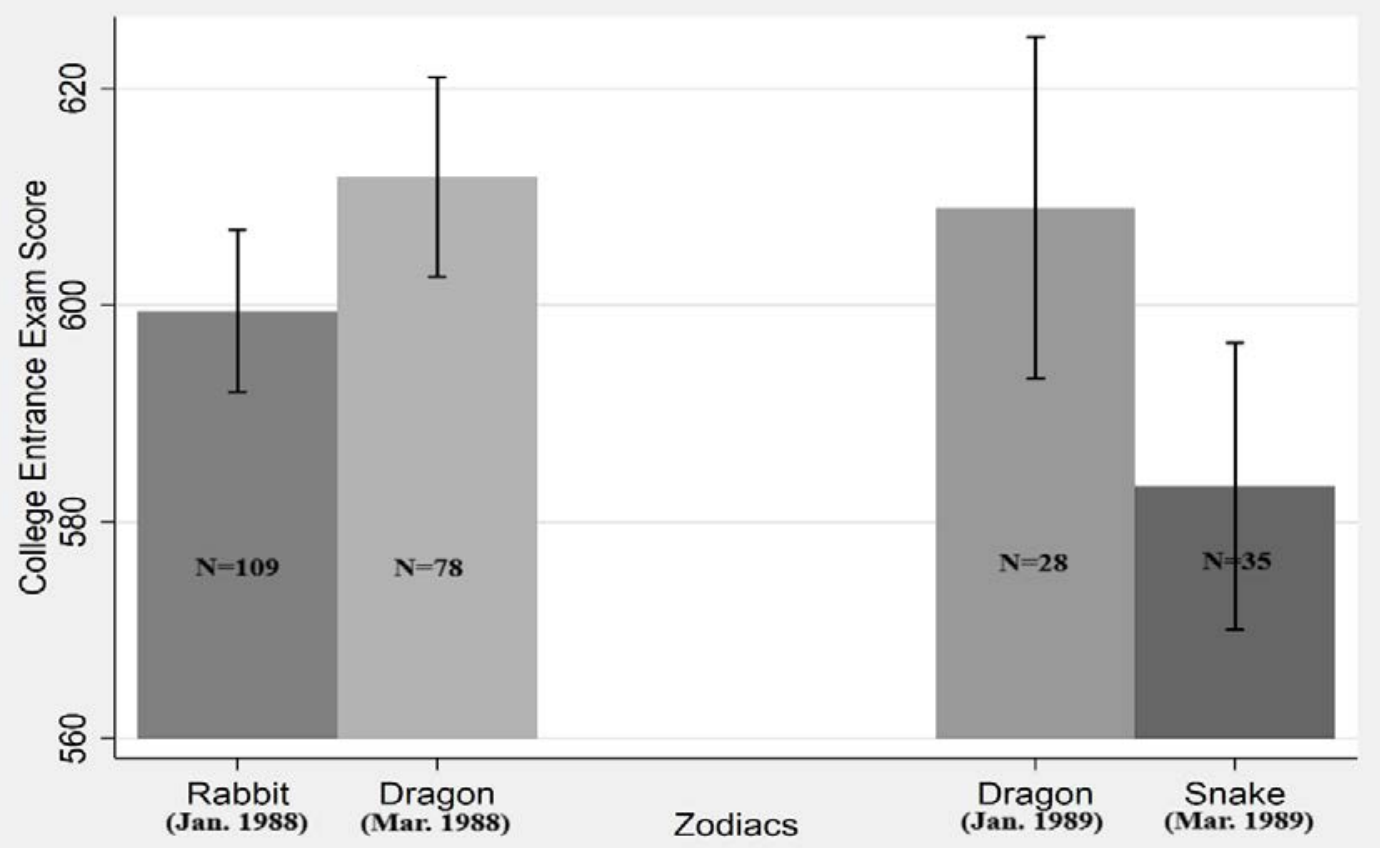


Table 1

Descriptive Statistics

Chinese General Social Survey Data

\begin{tabular}{|c|c|c|c|c|}
\hline "Variables & Details & Dragon & $\begin{array}{l}\text { Non- } \\
\text { Dragon }\end{array}$ & $\begin{array}{l}\text { Diff. of } \\
\text { Mean } \\
(p \text {-value })\end{array}$ \\
\hline $\begin{array}{l}\text { Bachelor Degree } \\
\text { or Above }\end{array}$ & $\begin{array}{l}\text { Dummy variable }(=1) \text { if the } \\
\text { respondent has a bachelor's } \\
\text { degree or higher. }\end{array}$ & $\begin{array}{c}0.353 \\
(0.478)\end{array}$ & $\begin{array}{c}0.281 \\
(0.449)\end{array}$ & 0.000 \\
\hline Age & Age of the respondent. & $\begin{array}{l}24.38 \\
(1.74)\end{array}$ & $\begin{array}{l}24.75 \\
(2.71)\end{array}$ & 0.002 \\
\hline Female & $\begin{array}{l}\text { Dummy variable }(=1) \text { if the } \\
\text { respondent is female. }\end{array}$ & $\begin{array}{c}0.514 \\
(0.500)\end{array}$ & $\begin{array}{c}0.528 \\
(0.499)\end{array}$ & 0.560 \\
\hline Minority & $\begin{array}{l}\text { Dummy variable }(=1) \text { if the } \\
\text { respondent belongs to a minority } \\
\text { group in China. }\end{array}$ & $\begin{array}{c}0.082 \\
(0.274)\end{array}$ & $\begin{array}{c}0.102 \\
(0.302)\end{array}$ & 0.141 \\
\hline $\begin{array}{l}\text { Father Bachelor } \\
\text { Degree or Above }\end{array}$ & $\begin{array}{l}\text { Dummy variable }(=1) \text { if the } \\
\text { respondent's father has at least a } \\
\text { bachelor's degree. }\end{array}$ & $\begin{array}{c}0.074 \\
(0.262)\end{array}$ & $\begin{array}{c}0.069 \\
(0.254)\end{array}$ & 0.662 \\
\hline $\begin{array}{l}\text { Mother Bachelor } \\
\text { Degree or } \\
\text { Above }\end{array}$ & $\begin{array}{l}\text { Dummy variable }(=1) \text { if the } \\
\text { respondent's mother has at least } \\
\text { a bachelor's degree. }\end{array}$ & $\begin{array}{c}0.042 \\
(0.200)\end{array}$ & $\begin{array}{c}0.041 \\
(0.199)\end{array}$ & 0.979 \\
\hline $\mathrm{N}$ & & 552 & 3,283 & \\
\hline
\end{tabular}

The sample consists of adults who were born between 1985-1991. Data are from China General Social Survey waves 2010, 2012, 2013, and 2015. Regressions include parents' occupational characteristics not listed here. There is a total of 34 categories of occupations (17 for father and 17 for mother). These 17 categories are: 1 . Employed by others (having a fixed employer); 2.full-time farmer; 3. Part-time farmer; 4. Contract employee/dispatched worker; 5. Casual worker (no fixed employer); 6. Working in family business, with salary; 7. Working in family business, no salary; 8. Freelance; 9. Individual business; 10. Owner or partner of a business; 11. Retired; 12. Unemployed; 13. Disabled; 14. In school without having a job; 15. Does housework; 16. Passed away; 17. Others. 
Table 2

Descriptive Statistics

Beijing College Students Survey Data

\begin{tabular}{|c|c|c|c|c|c|}
\hline Variables & Details & Mean & $\begin{array}{l}\text { Std. } \\
\text { Dev. }\end{array}$ & Mean & $\begin{array}{l}\text { Std. } \\
\text { Dev }\end{array}$ \\
\hline $\begin{array}{l}\text { National College } \\
\text { Entrance Exam } \\
\text { Score }\end{array}$ & $\begin{array}{l}\text { The student's score in the } \\
\text { National College Entrance } \\
\text { Exam in China. }\end{array}$ & 602.7 & 49.94 & 602.48 & 50.21 \\
\hline Dragon & $\begin{array}{l}\text { Dummy variable }(=1) \text { if the } \\
\text { student's zodiac sign is } \\
\text { Dragon. }\end{array}$ & 0.23 & 0.42 & 0.23 & 0.42 \\
\hline Female & $\begin{array}{l}\text { Dummy variable }(=1) \text { if the } \\
\text { student is female. }\end{array}$ & 0.47 & 0.50 & 0.47 & 0.50 \\
\hline Minority & $\begin{array}{l}\text { Dummy variable }(=1) \text { if the } \\
\text { student is from an ethnic } \\
\text { minority in China. }\end{array}$ & 0.12 & 0.32 & 0.11 & 0.32 \\
\hline $\begin{array}{l}\text { Took Multiple } \\
\text { Exams }\end{array}$ & $\begin{array}{l}\text { Dummy variable }(=1) \text { if the } \\
\text { student took the National } \\
\text { College Entrance Exam } \\
\text { multiple times. }\end{array}$ & 0.10 & 0.31 & 0.10 & 0.30 \\
\hline $\begin{array}{l}\text { Good Family Econ } \\
\text { Status }\end{array}$ & $\begin{array}{l}\text { Dummy variable }(=1) \text { if the } \\
\text { student's family economic } \\
\text { status is better or much } \\
\text { better than local average. }\end{array}$ & & & 0.15 & 0.35 \\
\hline $\begin{array}{l}\text { Father Bachelor } \\
\text { Degree or Above }\end{array}$ & $\begin{array}{l}\text { Dummy variable }(=1) \text { if the } \\
\text { student's father has at least } \\
\text { a bachelor's degree. }\end{array}$ & & & 0.48 & 0.50 \\
\hline $\begin{array}{l}\text { Mother Bachelor } \\
\text { Degree or Above }\end{array}$ & $\begin{array}{l}\text { Dummy variable }(=1) \text { if the } \\
\text { student's mother has at } \\
\text { least a bachelor's degree. }\end{array}$ & & & 0.40 & 0.49 \\
\hline $\mathrm{N}$ & & 2,956 & & 2,738 & \\
\hline
\end{tabular}


Table 3

Summary Statistics

China Education Panel Study Data (Middle School Students)

\begin{tabular}{|c|c|c|c|c|}
\hline Variables & Details & Mean & $\begin{array}{l}\text { Std. } \\
\text { Dev. }\end{array}$ & $\mathrm{N}$ \\
\hline Test Score in Math & $\begin{array}{l}\text { The student's mid-term exam score in the subject of } \\
\text { Math. }\end{array}$ & 81.57 & 30.59 & 13,309 \\
\hline Test Score in Chinese & $\begin{array}{l}\text { The student's mid-term exam score in the subject of } \\
\text { Chinese. }\end{array}$ & 85.41 & 19.54 & 13,309 \\
\hline Test Score in English & $\begin{array}{l}\text { The student's mid-term exam score in the subject of } \\
\text { English. }\end{array}$ & 82.27 & 29.71 & 13,309 \\
\hline \multicolumn{5}{|l|}{ Student Characteristics } \\
\hline Dragon & $\begin{array}{l}\text { Dummy variable }(=1) \text { if the student's zodiac is } \\
\text { Dragon. }\end{array}$ & 0.23 & 0.42 & 14,954 \\
\hline BMI & The student’s Body Mass Index & 18.93 & 3.35 & 14,954 \\
\hline Female & Dummy variable $(=1)$ if the student is female. & 0.50 & 0.50 & 14,954 \\
\hline Age & $\begin{array}{l}\text { Age of the student measured as the survey year minus } \\
\text { the student's birth year. }\end{array}$ & 13.88 & 1.33 & 14,954 \\
\hline Single Child & Dummy variable $(=1)$ if the student is the single child. & 0.45 & 0.50 & 14,954 \\
\hline \multicolumn{5}{|l|}{ Students’ Self-Esteem } \\
\hline Articulate & $\begin{array}{l}\text { Dummy variable }(=1) \text { if the student believes that } \\
\text { he/she can present his/her opinions clearly. }\end{array}$ & 0.80 & 0.40 & 14,541 \\
\hline Fast Thinker & $\begin{array}{l}\text { Dummy variable }(=1) \text { if the student believes that } \\
\text { he/she react to things rapidly. }\end{array}$ & 0.77 & 0.42 & 14,537 \\
\hline Quick Learner & $\begin{array}{l}\text { Dummy variable }(=1) \text { if the student believes that } \\
\text { he/she learn new knowledge quickly. }\end{array}$ & 0.76 & 0.43 & 14,428 \\
\hline $\begin{array}{l}\text { Wants Bachelor or Higher } \\
\text { Degree }\end{array}$ & $\begin{array}{l}\text { Dummy variable }(=1) \text { if the student wants to get at } \\
\text { least a bachelor's degree in the future. }\end{array}$ & 0.67 & 0.47 & 14,954 \\
\hline Strong Career Ambition & $\begin{array}{l}\text { Dummy variable }(=1) \text { if the student wants to become } \\
\text { a leader or officer in national/government institutions, } \\
\text { a scientist, an engineer or an executive in a company } \\
\text { in the future. }\end{array}$ & 0.36 & 0.48 & 14,926 \\
\hline Has Faith in the Future & $\begin{array}{l}\text { Dummy variable }(=1) \text { if the student has faith in his/her } \\
\text { own future. }\end{array}$ & 0.86 & 0.35 & 14,954 \\
\hline \multicolumn{5}{|l|}{$\begin{array}{l}\text { Parents'Attributes, Investments } \\
\text { and Beliefs }\end{array}$} \\
\hline $\begin{array}{l}\text { Parents Hope Their Child to Get } \\
\text { at Least a High School } \\
\text { Diploma }\end{array}$ & $\begin{array}{l}\text { Dummy variable }(=1) \text { if parents hope that their child } \\
\text { should get at least a bachelor's degree in the future. }\end{array}$ & 0.93 & 0.25 & 13,764 \\
\hline $\begin{array}{l}\text { Parents Hope Their Child to Get } \\
\text { at Least a Bachelor Degree }\end{array}$ & $\begin{array}{l}\text { Dummy variable }(=1) \text { if parents hope that their child } \\
\text { should get at least a bachelor's degree in the future. }\end{array}$ & 0.76 & 0.42 & 13,764 \\
\hline $\begin{array}{l}\text { Parents have Strong Career } \\
\text { Ambition for Their Child }\end{array}$ & $\begin{array}{l}\text { Dummy variable }(=1) \text { if parents hope that their child } \\
\text { should get become a leader or officer in } \\
\text { national/government institutions, a scientist, an } \\
\text { engineer or an executive in a company in the future. }\end{array}$ & 0.43 & 0.50 & 13,829 \\
\hline $\begin{array}{l}\text { Parents Have Faith in Their } \\
\text { Child's Future }\end{array}$ & $\begin{array}{l}\text { Dummy variable }(=1) \text { if parents have faith in the } \\
\text { child's future. }\end{array}$ & 0.88 & 0.32 & 13,747 \\
\hline $\begin{array}{l}\text { Parents Require Their Child to } \\
\text { at Least Have Grades Higher } \\
\text { than Average (Reported by } \\
\text { Parents) }\end{array}$ & $\begin{array}{l}\text { Dummy variable }(=1) \text { if parents require the kids' } \\
\text { grades to be at least better than class average. }\end{array}$ & 0.73 & 0.45 & 13,769 \\
\hline
\end{tabular}


Table 3 (continued)

\begin{tabular}{|c|c|c|c|c|}
\hline $\begin{array}{l}\text { Parents Contact Teachers } \\
\text { Spontaneously More than } 5 \\
\text { Times This Semester }\end{array}$ & $\begin{array}{l}\text { Dummy variable }(=1) \text { if parents contact the teachers } \\
\text { of their kids spontaneously more than } 5 \text { times in this } \\
\text { semester. }\end{array}$ & 0.14 & 0.34 & 13,739 \\
\hline $\begin{array}{l}\text { Students Went to Kindergarten } \\
\text { after } 3 \text { Years Old }\end{array}$ & $\begin{array}{l}\text { Dummy variable }(=1) \text { if the student went to } \\
\text { kindergarten after } 3 \text { years old; }(=0) \text { if the student did } \\
\text { not go to kindergarten after } 3 \text { years old. }\end{array}$ & 0.81 & 0.39 & 13,765 \\
\hline Log (Pocket Money Weekly) & $\begin{array}{l}\text { Logarithm of the amount of pocket money the student } \\
\text { receives from parents every week on average. }\end{array}$ & 3.16 & 0.94 & 11,097 \\
\hline $\begin{array}{l}\text { Student Helping Parents with } \\
\text { Housework during the } \\
\text { Holidays }\end{array}$ & $\begin{array}{l}\text { Dummy variable }(=1) \text { if the student often helps parents } \\
\text { do housework during the summer and/or winter } \\
\text { holiday. }\end{array}$ & 0.55 & 0.50 & 13,760 \\
\hline $\begin{array}{l}\text { Student Helping Parents with } \\
\text { Housework Last Week }\end{array}$ & $\begin{array}{l}\text { Dummy variable }(=1) \text { if the student helps parents do } \\
\text { housework (1-15 hours) during the last week every } \\
\text { day. }\end{array}$ & 0.38 & 0.48 & 13,506 \\
\hline $\begin{array}{l}\text { Father Bachelor Degree or } \\
\text { Above }\end{array}$ & $\begin{array}{l}\text { Dummy variable }(=1) \text { if the student's father has at } \\
\text { least a bachelor's degree. }\end{array}$ & 0.16 & 0.37 & 14,954 \\
\hline $\begin{array}{l}\text { Mother Bachelor Degree or } \\
\text { Above }\end{array}$ & $\begin{array}{l}\text { Dummy variable }(=1) \text { if the student's mother has at } \\
\text { least a bachelor's degree. }\end{array}$ & 0.13 & 0.34 & 14,954 \\
\hline Father White Collar & $\begin{array}{l}\text { Dummy variable }(=1) \text { if the student's father has a } \\
\text { white collar or better job. }\end{array}$ & 0.19 & 0.39 & 14,954 \\
\hline Mother White Collar & $\begin{array}{l}\text { Dummy variable }(=1) \text { if the student's mother has a } \\
\text { white collar or better job. }\end{array}$ & 0.14 & 0.35 & 14,954 \\
\hline \multicolumn{5}{|l|}{ Family Income Status } \\
\hline $\begin{array}{l}\text { Family Has High Income } \\
\text { (Reported by Parents) }\end{array}$ & $\begin{array}{l}\text { Dummy variable }(=1) \text { if the student's family income } \\
\text { is above average (including average) now, reported by } \\
\text { parents. }\end{array}$ & 0.06 & 0.24 & 14,954 \\
\hline $\begin{array}{l}\text { Mother Answers the Parents’ } \\
\text { Survey }\end{array}$ & $\begin{array}{l}\text { Dummy variable }(=1) \text { if the student's mother answers } \\
\text { the survey questions for parents. }\end{array}$ & 0.53 & 0.50 & 13,829 \\
\hline
\end{tabular}

For the outcomes of parents' expectations, we only include parents who are biological parents of the students. Descriptive statistics of the students' type of hukou (certificate of residency) are not reported. 


\section{Table 4}

The Impact of Zodiacs on the Propensity of Having at Least a Bachelor's Degree CGSS Data

\begin{tabular}{|c|c|c|c|}
\hline Variables & $\begin{array}{c}(1) \\
\text { Bachelor Degree } \\
\text { or Above (born } \\
1985-1991)\end{array}$ & $\begin{array}{c}(2) \\
\text { Bachelor Degree } \\
\text { or Above (born } \\
1986-1990)\end{array}$ & $\begin{array}{c}(3) \\
\text { Bachelor Degree } \\
\text { or Above } \\
\text { (born 1987- } \\
\text { 1989) }\end{array}$ \\
\hline Dragon & $\begin{array}{c}0.07 * * * \\
(0.02)\end{array}$ & $\begin{array}{c}0.06 * * * \\
(0.02)\end{array}$ & $\begin{array}{c}0.06^{* * *} \\
(0.02)\end{array}$ \\
\hline Age & $\begin{array}{c}0.02 * * * \\
(0.00)\end{array}$ & $\begin{array}{c}0.03 * * * \\
(0.01)\end{array}$ & $\begin{array}{c}0.02 \\
(0.01)\end{array}$ \\
\hline Female & $\begin{array}{c}0.03 * * \\
(0.02)\end{array}$ & $\begin{array}{l}0.03^{*} \\
(0.02)\end{array}$ & $\begin{array}{c}0.06 * * * \\
(0.02)\end{array}$ \\
\hline Minority & $\begin{array}{c}0.01 \\
(0.04)\end{array}$ & $\begin{array}{c}0.01 \\
(0.04)\end{array}$ & $\begin{array}{c}0.03 \\
(0.04)\end{array}$ \\
\hline Father Bachelor Degree or Above & $\begin{array}{c}0.20 * * * \\
(0.04)\end{array}$ & $\begin{array}{c}0.21 * * * \\
(0.04)\end{array}$ & $\begin{array}{c}0.21 * * * \\
(0.05)\end{array}$ \\
\hline Mother Bachelor Degree or Above & $\begin{array}{c}0.04 \\
(0.05)\end{array}$ & $\begin{array}{c}0.06 \\
(0.07)\end{array}$ & $\begin{array}{c}0.06 \\
(0.09)\end{array}$ \\
\hline Parents’ Occupation Attributes & $\mathrm{Y}$ & $\mathrm{Y}$ & $\mathrm{Y}$ \\
\hline Mean of Dependent Variable & 0.30 & 0.31 & 0.31 \\
\hline Wave Fixed Effects & $\mathrm{Y}$ & $\mathrm{Y}$ & $\mathrm{Y}$ \\
\hline Province Fixed Effects & Y & $\mathrm{Y}$ & Y \\
\hline $\mathrm{N}$ & 3,835 & 2,850 & 1,714 \\
\hline
\end{tabular}


Table 5

The Impact of Zodiacs on the National College Entrance Exam Scores

BCSS Data

\begin{tabular}{|c|c|c|c|c|c|c|}
\hline Variables & $\begin{array}{c}(1) \\
\text { National } \\
\text { College } \\
\text { Entrance Exam } \\
\text { Score }\end{array}$ & $\begin{array}{c}(2) \\
\text { National } \\
\text { College } \\
\text { Entrance Exam } \\
\text { Score }\end{array}$ & $\begin{array}{c}(3) \\
\text { National } \\
\text { College } \\
\text { Entrance } \\
\text { Exam Score } \\
\text { (born 1987- } \\
\text { 1989) }\end{array}$ & $\begin{array}{c}(4) \\
\text { National } \\
\text { College } \\
\text { Entrance } \\
\text { Exam Score }\end{array}$ & $\begin{array}{c}\text { (5) } \\
\text { National } \\
\text { College } \\
\text { Entrance } \\
\text { Exam Score }\end{array}$ & $\begin{array}{c}(6) \\
\text { National } \\
\text { College } \\
\text { Entrance } \\
\text { Exam Score } \\
\text { (born 1987- } \\
1989) \\
\end{array}$ \\
\hline & & & & \multicolumn{3}{|c|}{ Using Adjusted Dragon Dummy } \\
\hline Dragon & $\begin{array}{c}10.50 * * * \\
(2.72)\end{array}$ & $\begin{array}{c}8.80 * * * \\
(2.42)\end{array}$ & $\begin{array}{c}9.12 * * * \\
(2.13)\end{array}$ & $\begin{array}{c}10.36 * * * \\
(2.61)\end{array}$ & $\begin{array}{c}8.38 * * * \\
(2.15)\end{array}$ & $\begin{array}{c}8.67 * * * \\
(1.85)\end{array}$ \\
\hline Female & $\begin{array}{c}-7.11 * * * \\
(0.94)\end{array}$ & $\begin{array}{c}-8.49 * * * \\
(1.09)\end{array}$ & $\begin{array}{c}-8.22 * * * \\
(1.25)\end{array}$ & $\begin{array}{c}-7.06^{* * * *} \\
(0.97)\end{array}$ & $\begin{array}{c}-8.43^{* * *} \\
(1.12)\end{array}$ & $\begin{array}{c}-8.14 * * * \\
(1.24)\end{array}$ \\
\hline Minority & $\begin{array}{c}-8.02 * * * \\
(2.08)\end{array}$ & $\begin{array}{c}-6.11 * * * \\
(2.15)\end{array}$ & $\begin{array}{c}-6.52 * * * \\
(1.70)\end{array}$ & $\begin{array}{c}-8.00 * * * \\
(2.08)\end{array}$ & $\begin{array}{c}-6.10 * * * \\
(2.14)\end{array}$ & $\begin{array}{c}-6.51 * * * \\
(1.68)\end{array}$ \\
\hline Took Multiple Exams & $\begin{array}{l}-0.22 \\
(2.69)\end{array}$ & $\begin{array}{c}1.83 \\
(2.51)\end{array}$ & $\begin{array}{c}2.64 \\
(2.02)\end{array}$ & $\begin{array}{l}-0.34 \\
(2.65)\end{array}$ & $\begin{array}{c}1.69 \\
(2.45)\end{array}$ & $\begin{array}{c}2.48 \\
(1.97)\end{array}$ \\
\hline Good Family Econ Status & & $\begin{array}{c}3.87 \\
(2.80)\end{array}$ & $\begin{array}{c}5.00 \\
(3.57)\end{array}$ & & $\begin{array}{c}3.88 \\
(2.77)\end{array}$ & $\begin{array}{c}5.02 \\
(3.55)\end{array}$ \\
\hline Father Bachelor Degree or Above & & $\begin{array}{c}9.84 * * * \\
(2.51)\end{array}$ & $\begin{array}{c}8.04 * * * \\
(2.80)\end{array}$ & & $\begin{array}{c}9.89 * * * \\
(2.53)\end{array}$ & $\begin{array}{c}8.10 * * * \\
(2.83)\end{array}$ \\
\hline Mother Bachelor Degree or Above & & $\begin{array}{c}7.55^{* * * *} \\
(1.44)\end{array}$ & $\begin{array}{c}7.78 * * * \\
(2.37)\end{array}$ & & $\begin{array}{c}7.47 * * * \\
(1.42)\end{array}$ & $\begin{array}{c}7.68 * * * \\
(2.35)\end{array}$ \\
\hline Average Exam Score & 602.69 & 602.48 & 602.16 & 602.69 & 602.48 & 602.16 \\
\hline Province Fixed Effects & $\mathrm{Y}$ & $\mathrm{Y}$ & Y & $\mathrm{Y}$ & Y & Y \\
\hline $\mathrm{N}$ & 2,956 & 2,738 & 2,029 & 2,956 & 2,738 & 2,029 \\
\hline
\end{tabular}

The data are collected from the Beijing College Student Study wave 2009. Standard errors are clustered at city level and reported in the parentheses. *significant at $10 \%$, ** significant at $5 \%$, *** significant at $1 \%$. 


\section{Table 6}

The Impact of Dragon Zodiac on Mid-Term Test Scores in Middle School CEPS Data

\begin{tabular}{lccc}
\hline \hline & $(1)$ & $(2)$ & $(3)$ \\
Variables & Test Score in & Test Score in & Test Score in \\
& Math & Chinese & English \\
\hline Dragon & 0.306 & $0.695^{* *}$ & $0.924^{* *}$ \\
& $(0.571)$ & $(0.284)$ & $(0.467)$ \\
Female & $1.525^{* * *}$ & $6.816^{* * *}$ & $11.031^{* * *}$ \\
& $(0.489)$ & $(0.253)$ & $(0.458)$ \\
Age & $-3.600^{* * *}$ & $-1.309 * * *$ & $-3.057 * * *$ \\
& $(0.418)$ & $(0.195)$ & $(0.347)$ \\
Single Child & 0.402 & -0.090 & $0.927^{* *}$ \\
& $(0.538)$ & $(0.271)$ & $(0.455)$ \\
Father Bachelor Degree or Above & $4.680^{* * *}$ & $1.951^{* * *}$ & $4.131^{* * *}$ \\
& $(0.863)$ & $(0.409)$ & $(0.712)$ \\
Mother Bachelor Degree or Above & $3.328 * * *$ & $1.077 * * *$ & $3.592^{* * *}$ \\
& $(0.758)$ & $(0.387)$ & $(0.621)$ \\
Father White Collar & 0.526 & 0.479 & 0.461 \\
& $(0.647)$ & $(0.317)$ & $(0.563)$ \\
Mother White Collar & -0.128 & 0.497 & 0.644 \\
& $(0.680)$ & $(0.361)$ & $(0.650)$ \\
Family Has High Income & $-1.950^{* *}$ & -0.376 & $-1.253^{*}$ \\
& $(0.881)$ & $(0.420)$ & $(0.715)$ \\
Mother Answers the Parents & $0.862 * *$ & 0.057 & 0.375 \\
Survey & & & \\
& $(0.438)$ & $(0.225)$ & $(0.389)$ \\
Average Mid-Term Exam Scores & 81.57 & 85.41 & 82.27 \\
Classroom Fixed Effects & Y & Y & Y \\
N & 13,309 & 13,309 & 13,309 \\
\hline Dependent variables are scores in Mathematics, Chinese and English on mid-term tests. The age \\
of the students ranges from 11 to 18. Students' type of hukou (certificate of residency) are \\
controlled for. Standard errors are clustered at classroom level and reported in the parentheses. \\
*significant at 10\%, ** significant at 5\%, *** significant at $1 \%$. & \\
& & &
\end{tabular}


Table 7

The Impact of Dragon Zodiac on Middle School Students' Self-Esteem and Expectations about the Future

CEPS Sample

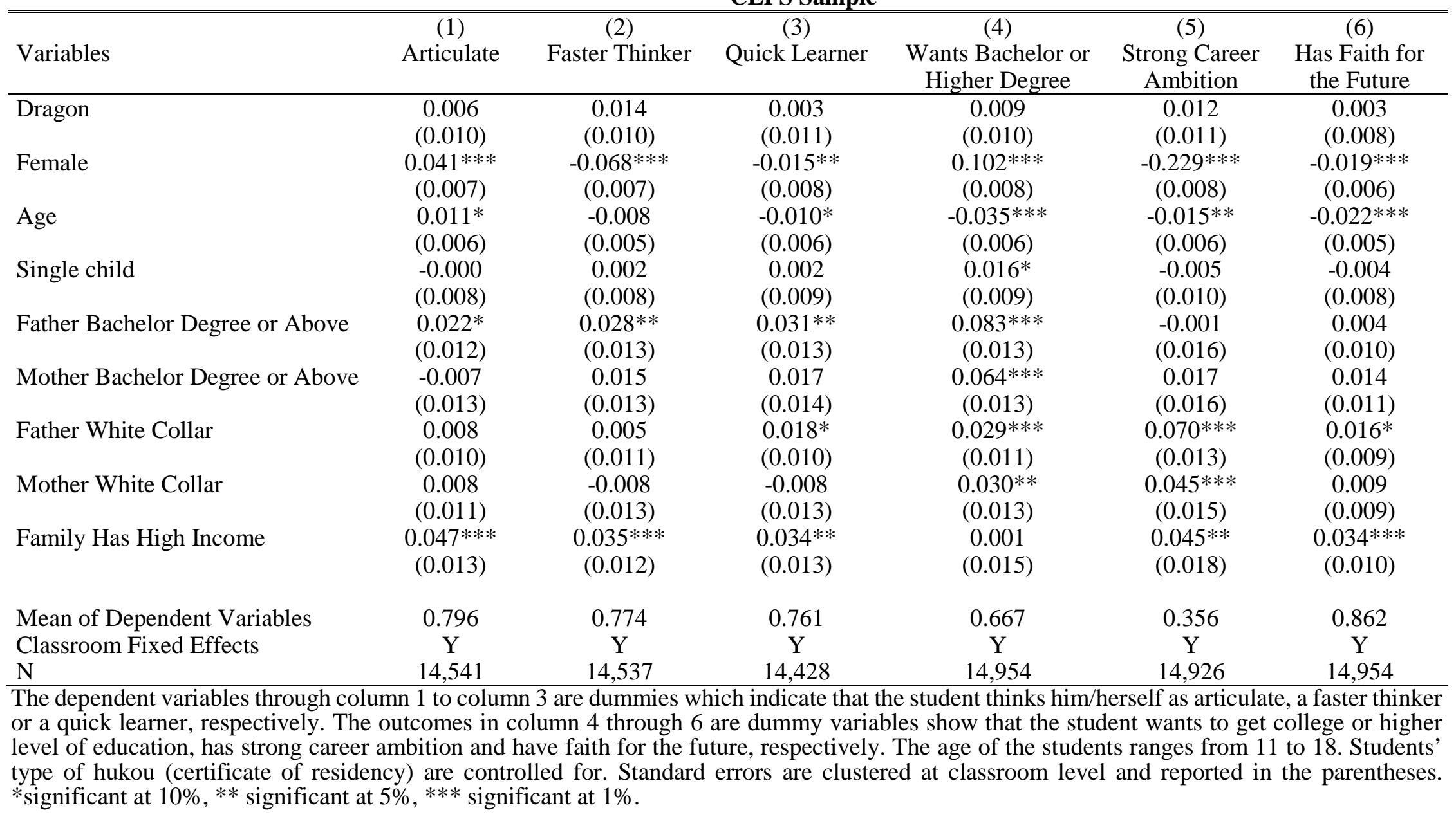


Table 8

The Relationship between being born in a Dragon year and Parent Attributes

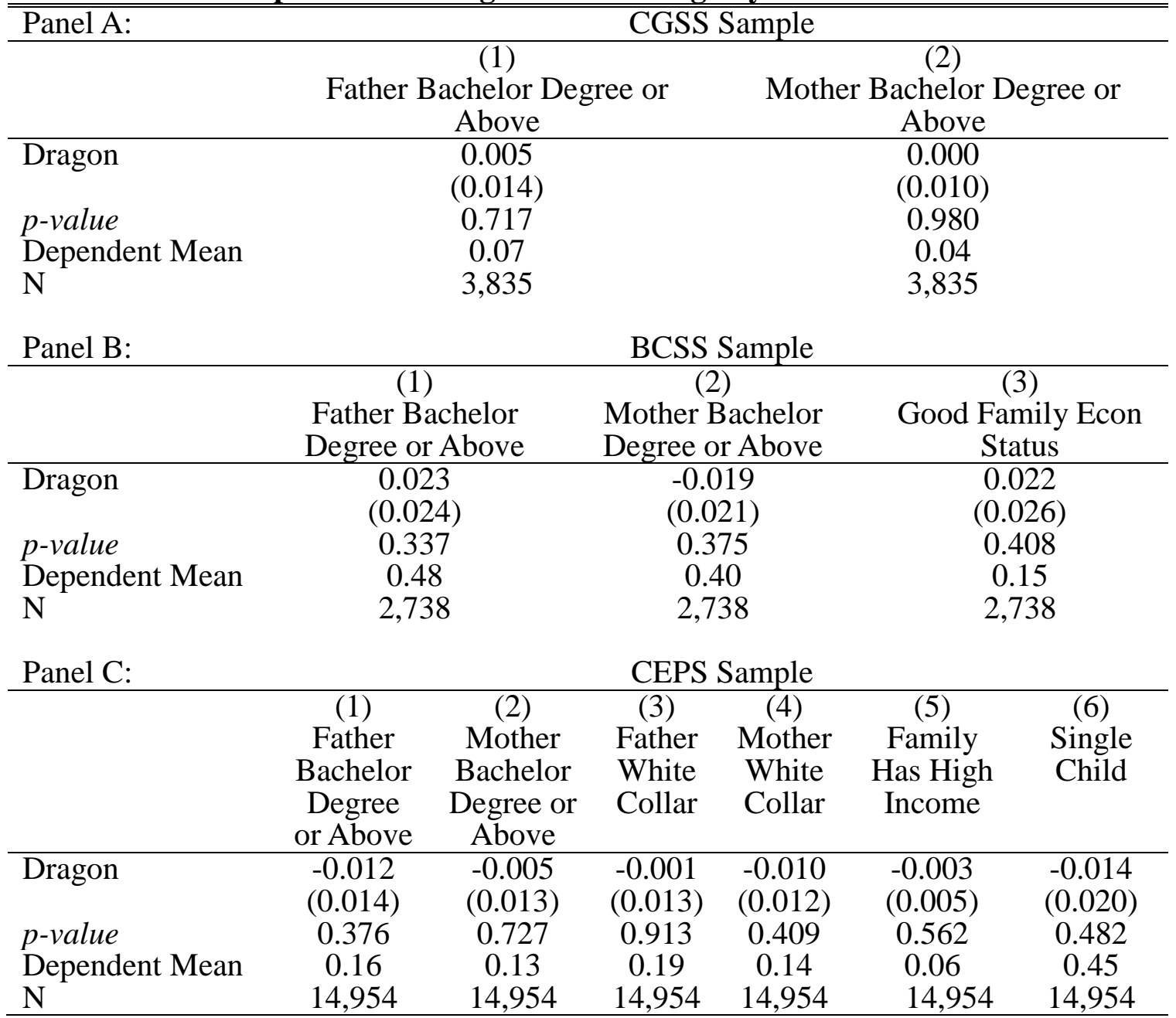

Standard errors are clustered at city level in panel A and B, at classroom level in panel C. All standard errors are reported in the parentheses. *significant at $10 \%, * *$ significant at $5 \%, * * *$ significant at $1 \%$. 
Table 9

Parents' Expectations of their Children

CEPS Data

(1) (2) (3)

Variables

Parents Hope Their Parents Hope Their Parents Have

(3)

Child to Get at Least a Child to Get at Least

Strong Career

Ambition for

Their Child

(4)

(5)

High School Diploma a Bachelor Degree

Parents Have

Parents Require

Faith in Their Their Child to at

Child's Future Least Have Grades

Higher than

\begin{tabular}{|c|c|c|c|c|c|}
\hline & & & & & Average \\
\hline Parent of a Dragon Child & $\begin{array}{c}0.017^{* * *} \\
(0.006)\end{array}$ & $\begin{array}{c}0.024^{* *} \\
(0.010)\end{array}$ & $\begin{array}{c}0.032^{* * *} \\
(0.011)\end{array}$ & $\begin{array}{c}0.006 \\
(0.007)\end{array}$ & $\begin{array}{c}0.024^{* *} \\
(0.011)\end{array}$ \\
\hline Female & $\begin{array}{c}0.019 * * * \\
(0.004)\end{array}$ & $\begin{array}{c}0.039 * * * \\
(0.007)\end{array}$ & $\begin{array}{c}-0.179 * * * \\
(0.008)\end{array}$ & $\begin{array}{c}0.024 * * * \\
(0.006)\end{array}$ & $\begin{array}{c}0.040 * * * \\
(0.008)\end{array}$ \\
\hline Age & $\begin{array}{c}-0.021 * * * \\
(0.004)\end{array}$ & $\begin{array}{c}-0.051 * * * \\
(0.007)\end{array}$ & $\begin{array}{c}-0.023 * * * \\
(0.007)\end{array}$ & $\begin{array}{c}-0.019 * * * \\
(0.005)\end{array}$ & $\begin{array}{c}-0.041 * * * \\
(0.007)\end{array}$ \\
\hline Single Child & $\begin{array}{l}0.010 * \\
(0.005)\end{array}$ & $\begin{array}{c}0.025^{* * *} \\
(0.008)\end{array}$ & $\begin{array}{c}-0.022^{*} \\
(0.012)\end{array}$ & $\begin{array}{c}-0.000 \\
(0.007)\end{array}$ & $\begin{array}{c}0.001 \\
(0.010)\end{array}$ \\
\hline Mother Answers the Parents' Survey & $\begin{array}{c}0.002 \\
(0.005)\end{array}$ & $\begin{array}{c}0.010 \\
(0.008)\end{array}$ & $\begin{array}{c}-0.033 * * * \\
(0.009)\end{array}$ & $\begin{array}{l}-0.004 \\
(0.006)\end{array}$ & $\begin{array}{c}-0.006 \\
(0.008)\end{array}$ \\
\hline Father Bachelor Degree or Above & $\begin{array}{c}0.020 * * * \\
(0.005)\end{array}$ & $\begin{array}{c}0.072^{* * *} \\
(0.010)\end{array}$ & $\begin{array}{c}0.000 \\
(0.018)\end{array}$ & $\begin{array}{l}-0.003 \\
(0.009)\end{array}$ & $\begin{array}{c}0.064^{* * *} * \\
(0.014)\end{array}$ \\
\hline Mother Bachelor Degree or Above & $\begin{array}{l}-0.000 \\
(0.005)\end{array}$ & $\begin{array}{c}0.015 \\
(0.010)\end{array}$ & $\begin{array}{c}-0.049 * * * \\
(0.018)\end{array}$ & $\begin{array}{c}0.025^{* * * *} \\
(0.009)\end{array}$ & $\begin{array}{c}0.009 \\
(0.017)\end{array}$ \\
\hline Father White Collar & $\begin{array}{l}-0.000 \\
(0.005)\end{array}$ & $\begin{array}{c}0.012 \\
(0.009)\end{array}$ & $\begin{array}{c}0.065^{* * *} * \\
(0.014)\end{array}$ & $\begin{array}{c}0.010 \\
(0.008)\end{array}$ & $\begin{array}{c}0.012 \\
(0.012)\end{array}$ \\
\hline Mother White Collar & $\begin{array}{c}0.007 \\
(0.005)\end{array}$ & $\begin{array}{c}0.033^{* * *} * \\
(0.010)\end{array}$ & $\begin{array}{l}0.031^{*} \\
(0.017)\end{array}$ & $\begin{array}{c}0.004 \\
(0.010)\end{array}$ & $\begin{array}{c}0.018 \\
(0.013)\end{array}$ \\
\hline Family Has High Income & $\begin{array}{l}-0.008 \\
(0.008)\end{array}$ & $\begin{array}{c}-0.003 \\
(0.014)\end{array}$ & $\begin{array}{l}0.034^{*} \\
(0.020)\end{array}$ & $\begin{array}{c}0.048^{* * *} \\
(0.009)\end{array}$ & $\begin{array}{l}-0.024 \\
(0.016)\end{array}$ \\
\hline $\begin{array}{l}\text { Mean of Dependent Variables } \\
\text { Classroom Fixed Effects } \\
\text { N }\end{array}$ & $\begin{array}{c}0.931 \\
\mathrm{Y} \\
13,764\end{array}$ & $\begin{array}{l}0.764 \\
Y \\
13,764\end{array}$ & $\begin{array}{c}0.433 \\
Y \\
13,829\end{array}$ & $\begin{array}{c}0.884 \\
Y \\
13,747\end{array}$ & $\begin{array}{l}0.727 \\
Y \\
13,769\end{array}$ \\
\hline
\end{tabular}

The dependent variables are dummies indicating whether parents expect their children to get at least a high school diploma, at least a bachelor degree, whether parents have strong career ambition for their child, and whether parents have faith in their children for the future. The age of the students ranges from 11 to 18. The sample only includes biological parents of the students. Student's type of hukou (certificate of residency) are controlled for. Adjusted p-values of the Dragon dummies for multiple-hypothesis testing using the Simes adjustment are $0.01,0.03,0.01$, 0.39 , and 0.03 for column 1 through 5 , respectively. Standard errors are clustered at classroom level and reported in the parentheses. *significant at $10 \%$, ** significant at $5 \%$, *** significant at $1 \%$. 
Table 10

The Impact of Dragon Zodiac on Mid-Term Test Scores in Middle School Accounting for Parent Expectations -- CEPS Data

\begin{tabular}{|c|c|c|c|}
\hline Variables & $\begin{array}{l}\text { (1) } \\
\text { Test Score in } \\
\text { Math }\end{array}$ & \begin{tabular}{c}
\multicolumn{1}{c}{$(2)$} \\
Test Score \\
in Chinese
\end{tabular} & $\begin{array}{c}\text { (3) } \\
\text { Test Score in } \\
\text { English }\end{array}$ \\
\hline Dragon & $\begin{array}{l}-0.613 \\
(0.519)\end{array}$ & $\begin{array}{c}0.300 \\
(0.262)\end{array}$ & $\begin{array}{c}0.200 \\
(0.418)\end{array}$ \\
\hline Female & $\begin{array}{c}0.623 \\
(0.435)\end{array}$ & $\begin{array}{c}6.386 * * * \\
(0.237)\end{array}$ & $\begin{array}{l}10.154 * * * \\
(0.433)\end{array}$ \\
\hline Age & $\begin{array}{l}-2.047 * * * \\
(0.361)\end{array}$ & $\begin{array}{l}-0.645^{* * *} \\
(0.177)\end{array}$ & $\begin{array}{l}-1.788 * * * \\
(0.310)\end{array}$ \\
\hline Single Child & $\begin{array}{c}0.102 \\
(0.476)\end{array}$ & $\begin{array}{l}-0.231 \\
(0.251)\end{array}$ & $\begin{array}{c}0.679 \\
(0.421)\end{array}$ \\
\hline Mother Answers the Parents' Survey & $\begin{array}{l}0.965 * * * \\
(0.359)\end{array}$ & $\begin{array}{c}0.091 \\
(0.202)\end{array}$ & $\begin{array}{c}0.443 \\
(0.335)\end{array}$ \\
\hline $\begin{array}{l}\text { Parents Hope Their Child to Get at Least } \\
\text { a High School Diploma }\end{array}$ & $\begin{array}{l}9.368 * * * \\
(1.030)\end{array}$ & $\begin{array}{l}4.719 * * * \\
(0.631)\end{array}$ & $\begin{array}{l}5.942 * * * \\
(0.903)\end{array}$ \\
\hline $\begin{array}{l}\text { Parents Hope Their Child to Get } \\
\text { Bachelor or Higher Degree }\end{array}$ & $\begin{array}{l}9.007 * * * \\
(0.681)\end{array}$ & $\begin{array}{l}3.804 * * * \\
(0.315)\end{array}$ & $\begin{array}{l}7.621 * * * \\
(0.572)\end{array}$ \\
\hline $\begin{array}{l}\text { Parents Have Strong Career Ambition } \\
\text { for Their Child }\end{array}$ & $\begin{array}{l}1.950 * * * \\
(0.410)\end{array}$ & $\begin{array}{c}0.601 * * * \\
(0.187)\end{array}$ & $\begin{array}{c}0.904 * * * \\
(0.343)\end{array}$ \\
\hline $\begin{array}{l}\text { Parents Have Faith in Their Child’s } \\
\text { Future }\end{array}$ & $\begin{array}{c}7.535 * * * \\
(0.703)\end{array}$ & $\begin{array}{c}2.732 * * * \\
(0.359)\end{array}$ & $\begin{array}{c}6.485^{* * *} \\
(0.578)\end{array}$ \\
\hline $\begin{array}{l}\text { Parents Require Their Child to at Least } \\
\text { Have Grades Higher than Average }\end{array}$ & $\begin{array}{c}17.123^{* * *} \\
(0.627)\end{array}$ & $\begin{array}{c}7.410 * * * \\
(0.321)\end{array}$ & $\begin{array}{c}14.769^{* * *} \\
(0.542)\end{array}$ \\
\hline Father Bachelor Degree or Above & $\begin{array}{c}2.777 * * * \\
(0.738)\end{array}$ & $\begin{array}{c}1.120 * * * \\
(0.356)\end{array}$ & $\begin{array}{c}2.537 * * * \\
(0.637)\end{array}$ \\
\hline Mother Bachelor Degree or Above & $\begin{array}{l}2.986^{* * *} \\
(0.701)\end{array}$ & $\begin{array}{c}0.931 * * * \\
(0.348)\end{array}$ & $\begin{array}{c}3.267 * * * \\
(0.561)\end{array}$ \\
\hline Father White Collar & $\begin{array}{c}0.014 \\
(0.578)\end{array}$ & $\begin{array}{c}0.281 \\
(0.288)\end{array}$ & $\begin{array}{c}0.069 \\
(0.485)\end{array}$ \\
\hline Mother White Collar & $\begin{array}{l}-0.803 \\
(0.639)\end{array}$ & $\begin{array}{c}0.212 \\
(0.346)\end{array}$ & $\begin{array}{l}0.104 \\
(0.593)\end{array}$ \\
\hline Family Has High Income & $\begin{array}{c}-1.948^{* *} \\
(0.791)\end{array}$ & $\begin{array}{l}-0.339 \\
(0.389)\end{array}$ & $\begin{array}{c}-1.243^{* *} \\
(0.626)\end{array}$ \\
\hline $\begin{array}{l}\text { Average Mid-Term Exam Scores } \\
\text { Classroom Fixed Effects } \\
\text { N }\end{array}$ & $\begin{array}{l}81.57 \\
Y \\
13,309\end{array}$ & $\begin{array}{c}85.41 \\
Y \\
13,309\end{array}$ & $\begin{array}{l}82.27 \\
\text { Y } \\
13,309\end{array}$ \\
\hline
\end{tabular}

The models control for a dummy variable which indicates who (father or mother) answered the parents' survey questions of parents' expectations. Dependent variables are scores in math, Chinese and English mid-term tests. The age of the students ranges from 11 to 18. Students' type of hukou (certificate of residency) are controlled for. Standard errors are clustered at classroom level and reported in the parentheses. *significant at 10\%, ** significant at 5\%, *** significant at $1 \%$. 
Table 11

Parents' Investment in their Children

CEPS Sample.

\begin{tabular}{|c|c|c|c|c|c|}
\hline Variables & $\begin{array}{c}(1) \\
\text { Parents Contact } \\
\text { Teachers } \\
\text { Spontaneously } \\
\text { More than 5 } \\
\text { Times This } \\
\text { Semester }\end{array}$ & $\begin{array}{c}(2) \\
\text { Student } \\
\text { Went to } \\
\text { Kindergarten } \\
\text { after } 3 \text { Years } \\
\text { Old }\end{array}$ & $\begin{array}{c}\text { (3) } \\
\text { Log (Pocket } \\
\text { Money } \\
\text { Weekly) }\end{array}$ & $\begin{array}{c}\text { (4) } \\
\text { Student } \\
\text { Helping } \\
\text { Parents with } \\
\text { Housework } \\
\text { during the } \\
\text { Holidays }\end{array}$ & $\begin{array}{c}(5) \\
\text { Student } \\
\text { Helping } \\
\text { Parents with } \\
\text { Housework } \\
\text { Last Week }\end{array}$ \\
\hline Parent of a Dragon Child & $\begin{array}{c}0.014 \\
(0.009)\end{array}$ & $\begin{array}{c}0.033 * * * \\
(0.010)\end{array}$ & $\begin{array}{c}0.050 * * \\
(0.024)\end{array}$ & $\begin{array}{c}-0.025 * * \\
(0.012)\end{array}$ & $\begin{array}{c}-0.027 * * \\
(0.012)\end{array}$ \\
\hline Female & $\begin{array}{c}-0.051 * * * \\
(0.006)\end{array}$ & $\begin{array}{c}0.009 \\
(0.006)\end{array}$ & $\begin{array}{l}0.011 \\
(0.017)\end{array}$ & $\begin{array}{c}0.098 * * * \\
(0.009)\end{array}$ & $\begin{array}{c}0.026 * * * \\
(0.009)\end{array}$ \\
\hline Age & $\begin{array}{c}-0.011^{* *} \\
(0.005)\end{array}$ & $\begin{array}{c}-0.050 * * * \\
(0.006)\end{array}$ & $\begin{array}{c}0.020 \\
(0.013)\end{array}$ & $\begin{array}{c}0.006 \\
(0.007)\end{array}$ & $\begin{array}{c}0.035^{* * * *} \\
(0.007)\end{array}$ \\
\hline Single Child & $\begin{array}{l}-0.002 \\
(0.008)\end{array}$ & $\begin{array}{c}0.024 * * * \\
(0.008)\end{array}$ & $\begin{array}{c}-0.044^{* *} \\
(0.020)\end{array}$ & $\begin{array}{c}-0.057 * * * \\
(0.012)\end{array}$ & $\begin{array}{c}-0.036 * * * \\
(0.011)\end{array}$ \\
\hline Mother Answers the Parents' Survey & $\begin{array}{l}-0.000 \\
(0.006)\end{array}$ & $\begin{array}{c}0.014^{* *} \\
(0.006)\end{array}$ & $\begin{array}{c}-0.079 * * * \\
(0.019)\end{array}$ & $\begin{array}{l}-0.008 \\
(0.009)\end{array}$ & $\begin{array}{l}-0.017^{*} \\
(0.009)\end{array}$ \\
\hline Father Bachelor Degree or Above & $\begin{array}{c}0.025 * * \\
(0.012)\end{array}$ & $\begin{array}{l}-0.009 \\
(0.010)\end{array}$ & $\begin{array}{c}-0.104 * * * \\
(0.033)\end{array}$ & $\begin{array}{c}0.003 \\
(0.016)\end{array}$ & $\begin{array}{l}-0.027^{*} \\
(0.014)\end{array}$ \\
\hline Mother Bachelor Degree or Above & $\begin{array}{c}0.033 * * * \\
(0.013)\end{array}$ & $\begin{array}{c}0.007 \\
(0.011)\end{array}$ & $\begin{array}{c}0.023 \\
(0.036)\end{array}$ & $\begin{array}{l}-0.001 \\
(0.017)\end{array}$ & $\begin{array}{c}0.001 \\
(0.015)\end{array}$ \\
\hline Father White Collar & $\begin{array}{l}0.019 * \\
(0.010)\end{array}$ & $\begin{array}{c}0.006 \\
(0.010)\end{array}$ & $\begin{array}{c}0.042 \\
(0.029)\end{array}$ & $\begin{array}{l}-0.015 \\
(0.014)\end{array}$ & $\begin{array}{l}-0.000 \\
(0.013)\end{array}$ \\
\hline Mother White Collar & $\begin{array}{c}0.028 * * * \\
(0.011)\end{array}$ & $\begin{array}{c}0.008 \\
(0.010)\end{array}$ & $\begin{array}{l}-0.006 \\
(0.033)\end{array}$ & $\begin{array}{l}-0.018 \\
(0.015)\end{array}$ & $\begin{array}{l}-0.000 \\
(0.016)\end{array}$ \\
\hline Family Has High Income & $\begin{array}{l}0.024^{*} \\
(0.014)\end{array}$ & $\begin{array}{c}0.012 \\
(0.012)\end{array}$ & $\begin{array}{c}0.429 * * * \\
(0.040)\end{array}$ & $\begin{array}{l}-0.016 \\
(0.018)\end{array}$ & $\begin{array}{c}0.018 \\
(0.017)\end{array}$ \\
\hline $\begin{array}{l}\text { Mean of Dependent Variables } \\
\text { Classroom Fixed Effects } \\
\mathrm{N}\end{array}$ & $\begin{array}{c}0.136 \\
Y \\
13,739\end{array}$ & $\begin{array}{c}0.813 \\
Y \\
13,765\end{array}$ & $\begin{array}{l}3.164 \\
Y \\
11,097\end{array}$ & $\begin{array}{l}0.545 \\
Y \\
13,760\end{array}$ & $\begin{array}{l}0.378 \\
\text { Y } \\
13,506\end{array}$ \\
\hline
\end{tabular}

The sample only includes biological parents of the students. The age of the students ranges from 11 to 18 . Students' type of hukou (certificate of residency) are controlled for. Standard errors are clustered at class level and reported in the parentheses.

*significant at $10 \%$, ** significant at $5 \%$, *** significant at $1 \%$. 


\section{Table 12}

The Impact of Dragon Zodiac on Middle School Students' Height

\begin{tabular}{|c|c|c|c|c|}
\hline VARIABLES & $\begin{array}{c}(1) \\
\text { Height } \\
\text { (Full Sample) }\end{array}$ & $\begin{array}{c}\text { (2) } \\
\text { Height } \\
\text { (Rural) }\end{array}$ & $\begin{array}{c}\text { (3) } \\
\text { Height } \\
\text { (Urban) }\end{array}$ & $\begin{array}{c}(4) \\
\text { Height } \\
\text { (Full Sample) }\end{array}$ \\
\hline Dragon & $\begin{array}{l}-0.384 \\
(0.266)\end{array}$ & $\begin{array}{l}-0.483 \\
(0.357)\end{array}$ & $\begin{array}{l}-0.156 \\
(0.413)\end{array}$ & $\begin{array}{l}-0.268 \\
(0.370)\end{array}$ \\
\hline Female & $\begin{array}{c}-6.446 * * * \\
(0.224)\end{array}$ & $\begin{array}{c}-6.065^{* * * *} \\
(0.280)\end{array}$ & $\begin{array}{c}-6.776 * * * \\
(0.307)\end{array}$ & $\begin{array}{c}-6.780 * * * \\
(0.290)\end{array}$ \\
\hline Rural & $\begin{array}{c}-0.807 * * * \\
(0.157)\end{array}$ & & & $\begin{array}{c}-1.231 * * * \\
(0.255)\end{array}$ \\
\hline Female*Dragon & $\begin{array}{c}2.722 * * * \\
(0.328)\end{array}$ & $\begin{array}{c}3.329 * * * \\
(0.412)\end{array}$ & $\begin{array}{c}1.920 * * * \\
(0.492)\end{array}$ & $\begin{array}{c}1.987 * * * \\
(0.470)\end{array}$ \\
\hline Rural*Dragon & & & & $\begin{array}{l}-0.225 \\
(0.465)\end{array}$ \\
\hline Rural*Female & & & & $\begin{array}{l}0.632 * \\
(0.334)\end{array}$ \\
\hline Rural*Female*Dragon & & & & $\begin{array}{c}1.432 * * \\
(0.578)\end{array}$ \\
\hline Mean of Height & 161.92 & 160.82 & 163.18 & 161.92 \\
\hline Classroom Fixed Effects & $\mathrm{Y}$ & $\mathrm{Y}$ & $\mathrm{Y}$ & $\mathrm{Y}$ \\
\hline $\mathrm{N}$ & 13,309 & 7,091 & 6,218 & 13,309 \\
\hline
\end{tabular}


Table 13

The Impact of Zodiacs on the Propensity of Having At least A Bachelor's Degree Regression Discontinuity (Local Linear Regressions) Estimates

\section{(CGSS Data)}

\begin{tabular}{|c|c|c|c|c|c|}
\hline Variables & $\begin{array}{c}(1) \\
\text { Bachelor or } \\
\text { Higher Degree } \\
(\mathrm{BW}=1 \mathrm{CCFT})\end{array}$ & $\begin{array}{c}(2) \\
\text { Bachelor or } \\
\text { Higher Degree } \\
(\mathrm{BW}=0.85 \text { CCFT) }\end{array}$ & $\begin{array}{c}(3) \\
\text { Bachelor or } \\
\text { Higher Degree } \\
(\mathrm{BW}=1.25 \mathrm{CCFT})\end{array}$ & $\begin{array}{c}(4) \\
\text { Bachelor or } \\
\text { Higher Degree } \\
(\mathrm{BW}=1.5 \mathrm{CCFT})\end{array}$ & $\begin{array}{c}(4) \\
\text { Bachelor or } \\
\text { Higher Degree } \\
(\mathrm{BW}=2 \mathrm{CCFT})\end{array}$ \\
\hline Dragon & $\begin{array}{c}0.09 * * \\
(0.04)\end{array}$ & $\begin{array}{l}0.08 * \\
(0.04)\end{array}$ & $\begin{array}{c}0.07^{*} \\
(0.04)\end{array}$ & $\begin{array}{c}0.08 * * \\
(0.04)\end{array}$ & $\begin{array}{c}0.07 * * \\
(0.03)\end{array}$ \\
\hline $\mathrm{N}$ & 1,827 & 1,418 & 2,585 & 3,295 & 4,695 \\
\hline$p$-value & 0.034 & 0.077 & 0.071 & 0.028 & 0.024 \\
\hline Mean of Outcome. & 0.30 & 0.30 & 0.30 & 0.30 & 0.30 \\
\hline
\end{tabular}


Table 14

Analyses of Narrow Windows (Individuals who are Born a few Months Apart)

\begin{tabular}{|c|c|c|c|}
\hline "Panel A (CEPS): & $\begin{array}{c}\text { (1) } \\
\text { Test Score in Math } \\
\text { (without controlling for } \\
\text { parents' expectations) }\end{array}$ & $\begin{array}{c}\text { (2) } \\
\text { Test Score in Chinese } \\
\text { (without controlling for } \\
\text { parents' expectations) }\end{array}$ & $\begin{array}{l}\text { (3) } \\
\text { Test Score in English } \\
\text { (without controlling for } \\
\text { parents’ expectations) }\end{array}$ \\
\hline $\begin{array}{c}\text { Dragon } \\
\mathrm{N}\end{array}$ & $\begin{array}{c}0.826 \\
(1.334) \\
847\end{array}$ & $\begin{array}{c}1.500 * * \\
(0.693) \\
847\end{array}$ & $\begin{array}{c}2.615 * * \\
(1.137) \\
847\end{array}$ \\
\hline Panel B (CEPS): & $\begin{array}{c}\text { (1) } \\
\text { Test Score in Math } \\
\text { (controlling for parents' } \\
\text { expectations) }\end{array}$ & $\begin{array}{c}(2) \\
\text { Test Score in Chinese } \\
\text { (controlling for parents' } \\
\text { expectations) }\end{array}$ & $\begin{array}{c}\text { (3) } \\
\text { Test Score in English } \\
\text { (controlling for parents' } \\
\text { expectations) }\end{array}$ \\
\hline $\begin{array}{l}\text { Dragon } \\
\qquad \mathrm{N}\end{array}$ & $\begin{array}{c}-0.699 \\
(1.224) \\
847\end{array}$ & $\begin{array}{c}0.864 \\
(0.647) \\
847\end{array}$ & $\begin{array}{c}1.386 \\
(1.053) \\
847\end{array}$ \\
\hline Panel C (BCSS): & \multicolumn{3}{|c|}{$\begin{array}{c}(1) \\
\text { National College Entrance Exam Score }\end{array}$} \\
\hline Dragon & \multicolumn{3}{|c|}{$\begin{array}{c}12.775^{* *} \\
(6.064) \\
250\end{array}$} \\
\hline
\end{tabular}

Regressions in Panel A and Panel B correspond to the regressions in Table 6 and Table 10, respectively. Regressions in Panel C correspond to those in Tables 5, respectively. 


\section{References}

Agarwal, Sumit, Qian, Wenlan, Sing, Tien Foo and Tan, Poh Lin, 2017. “Dragon Babies”, Georgetown McDonough School of Business Research Paper, No. 3032575.

Alesina, Alberto and Fuchs-Schündeln, Nicola, 2007. “Goodbye Lenin (or Not?): The Effect of Communism on People's Preferences”, American Economic Review, vol. 97, pp. 1507-1528.

Alesina, Alberto and Giuliano, Paola, 2011. "Family Ties and Political Participation”, Journal of the European Economic Association, vol. 9, pp. 817-839.

Alesina, Alberto, Giuliano, Paola and Nunn, Nathan, 2013. "On the Origins of Gender Roles: Women and the Plough”, The Quarterly Journal of Economics, vol. 128, pp. 469-530.

Bénabou, Roland, 2015. “The Economics of Motivated Beliefs", Revue d'Economie Politique, vol. 125, pp. 665-685.

Bénabou, Roland and Tirole, Jean, 2016. "Mindful Economics: The Production, Consumption, and Value of Beliefs", The Journal of Economic Perspectives, vol. 30, pp. 141-164.

Bharadwaj, Prashant, Eberhard, Juan Pedro and Neilson, Christopher A., 2018. "Health at Birth, Parental Investments, and Academic Outcomes”, Journal of Labor Economics, vol. 36, pp. 349-394.

Brunello, Giorgio, Paola, Maria, and Scoppa, Vincenzo, 2010. "Peer Effects in Higher Education: Does the Field of Study Matter?”, Economic Inquiry, vol. 48, pp. 621634.

Cabrera, Jose Maria and Webbink, Dinand, 2019. "Do Higher Salaries Yield Better Teachers and Better Student Outcomes?”, Journal of Human Resource, Forthcoming.

Calonico, Sebastian, Cattaneo, Matias D., Farrell, Max H. and Titiunik, Rocio, 2018. "Regression Discontinuity Designs Using Covariates", The Review of Economics and Statistics, Just Accepted.

Calonico, Sebastian, Cattaneo, Matias D., Farrell, Max H. and Titiunik, Rocio, 2017. "Rdrobust: Software for Regression-Discontinuity Designs”, The Stata Journal, vol. 17, pp. 372-404.

Case, Anne and Paxson, Christina, 2008. "Stature and Status: Height, Ability, and Labor Market Outcomes”, Journal of Political Economy, vol. 116, pp. 499-532.

Cattaneo, Matias D., Jansson, Michael, and Ma, Xinwei, 2018. "Manipulation Testing Based on Density Discontinuity”, The Stata Journal, vol. 18, pp. 234-261.

Cook, Justin C. and Fletcher, Jason M., 2015. "Understanding Heterogeneity in the Effects of Birth Weight on Adult Cognition and Wages", Journal of Health Economics, vol. 41, pp. 107-116.

Di Tella, Rafael, Galiant, Sebastian and Schargrodsky, Ernesto, 2007. "The Formation of Beliefs: Evidence from the Allocation of Land Titles to Squatters”, The Quarterly Journal of Economics, vol. 122, pp. 209-241.

Do, Quy-Toan and Phung, Tung D., 2010. “The Importance of Being Wanted”, American Economic Journal: Applied Economics, vol. 2, pp. 236-253.

Erten, Bilge and Keskin, Pinar, 2018. "For Better or for Worse?: Education and the Prevalence of Domestic Violence in Turkey”, American Economic Journal: Applied Economics, vol. 10, pp. 64-105. 
Fernandez, Raquel, and Fogli, Alessandra, 2009. "Culture: An Empirical Investigation of Beliefs, Work, and Fertility”, American Economic Journal: Macroeconomics, vol. 1, pp. 146-177.

Figlio, David, Guryan, Jonathan, Karbownik, Krzysztof and Roth, Jeffrey, 2014. "The Effects of Poor Neonatal Health on Children's Cognitive Development”, The American Economic Review, vol. 104, pp. 3921-3955.

Gelman, Andrew and Imbens, guido, 2017. "Why High-Order Polynomials Should Not Be Used in Regression Discontinuity Designs”, Journal of Business \& Economic Statistics, 1-10.

Goodkind, Daniel M., 1991. "Creating New Traditions in Modern Chinese Populations: Aiming for Birth in the Year of the Dragon”, Population and Development Review, vol. 17, pp. 663-686.

Guiso, Luigi, Sapienza, Paola, and Zingales, Luigi, 2008. "Social Capital as Good Culture”, Journal of the European Economic Association, vol. 6, pp. 295-320.

Guiso, Luigi, Sapienza, Paola, and Zingales, Luigi, 2009. "Cultural Biases in Economic Exchange?”, The Quarterly Journal of Economics, vol. 124, pp. 1095-1131.

Hanushek, Eric A., Kain, John F., and Rivkin, Steven G., 2009. "New Evidence about Brown V. Board of Education: The Complex Effects of School Racial Composition on Achievement”, Journal of Labor Economics, vol. 27, pp. 349-383.

Hoekstra, Mark, Mouganie, Pierre, and Wang, Yaojing, 2018. "Peer Quality and the Academic Benefits to Attending Better Schools", Journal of Labor Economics, vol. 36, pp. 841-884.

Johnson, Noel D. and Nye, John V.C., 2011. “Does Fortune Favor Dragons?”, Journal of Economic Behavior \& Organization, Vol.78, pp. 85-97.

Lau, Yan. 2019. "The Dragon Cohort of Hong Kong: Traditional beliefs, Demographics and Education” Journal of Population Economics, 32: 219-246.

Lavy, Victor, Paserman, M. Daniele, and Schlosser, Analia, 2012. "Inside the Black Box of Ability Peer Effects: Evidence from Variation in the Proportion of Low Achievers in the Classroom", The Economic Journal, vol. 122, pp. 208-237.

Li, Zhonglu, 2016. "Family Background, Academic Performance and Admission to Postgraduate Study in China", Chinese Journal of Sociology (a Chinese Journal), vol. 36, pp. 86-109.

Lim Jaegeum, and Meer, Jonathan, 2017. "The Impact of Teacher-Student Gender Matches: Random Assignment Evidence from South Korea”, Journal of Human Resources, Forthcoming.

Mocan, Naci, Samantha Bielen and Wim Marneffe, 2018. "Quality of Judicial institutions, Crimes, Misdemeanors, and Dishonesty," NBER Working Paper No: 24396.

Mocan, Naci and Pogorelova, Luiza, 2015. "Why Work More? The Impact of Taxes, and Culture of Leisure on Labor Supply in Europe”, NBER Working Paper, No. 21297.

Mocan, Naci and Raschke, Christian, 2016. "Economic Well-being and Anti-Semitic, Xenophobic, and Racist Attitudes in Germany”, European Journal of Law and Economics, vol. 41, pp. 1-63.

Newcombe, Rhiannon, Milne, Barry J., Caspi, Avshalom, Poulton, Richie and Moffitt, Terrie E., 2007. "Birthweight Predicts IQ: Fact or Artefact?”, Twin Research and Human Genetics, vol. 10, pp. 581-586. 
Nunn, Nathan and Sanchez de la Sierra, Raul, 2017. "Why Being Wrong Can Be Right: Magical Warfare Technologies and the Persistence of False Beliefs", American Economic Review: Papers \& Proceedings, vol. 107, pp. 582-587.

Pop-Eleches, Christian, and Urquiola, Miguel, 2013. "Going to a Better School: Effects and Behavioral Responses”, American Economic Review, vol. 103, pp. 1289-1324.

Rosenzweig, Mark and Zhang, Junsen, 2013. "Economic Growth, Comparative Advantage, and Gender Differences in Schooling Outcomes: Evidence from the Birthweight Differences of Chinese Twins", Journal of Development Economics, vol. 104, pp. 245-260.

Royer, Heather, 2009. "Separated at Girth: US Twin Estimates of the Effects of Birth Weight”, American Economic Journal: Applied Economics, vol. 1, pp. 49-85.

Sim, Nicholas, 2015. "Astronomics in Action: The Graduate Earnings Premium and the Dragon Effect in Singapore”, Economic Inquiry, vol. 53, pp. 922-939.

Sim, Shuan, 2015. "Chinese Mothers Not Keen On Births During Year Of The Sheep Because of Zodiac Superstitions", International Business Times.

Suen, Wing, 2004. “The Self-Perpetuation of Biased Beliefs”, The Economic Journal, vol. 114, pp. 377-396.

Vere, James P., 2008. "Dragon Children: Identifying the Causal Effect of the First Child on Female Labor Supply with the Chinese Lunar Calendar", Oxford Bulletin of Economics and Statistics, vol. 70, pp. 303-325.

Voigtländer, Nico and Voth, Hans-Joachim, 2012. "Persecution Perpetuated: The Medieval Origins of Anti-Semitic Violence in Nazi Germany", The Quarterly Journal of Economics, vol. 127, pp. 1339-1392.

Wan, William, 2014. "Chinese Couples Rush to Get Pregnant before Dreaded Year of the Sheep", The Washington Post, May 9

Wuddun, Sheryl, 1992. "It's Year of the Monkey, and Good for Babies”, The New York Times.

Wong, Ka-Fu and Yung, Linda, 2005. “Do Dragons Have Better Fate?”, Economic Inquiry, vol. 43, pp. 689-697.

Ye, Hua, 2015. "Key-Point Schools and Entry into Tertiary Education in China”, Chinese Sociological Review, vol. 47, pp. 128-153.

Yi, Zeng, 1996. "Is Fertility in China in 1991-92 Far below Replacement Level?", Population Studies, vol. 50, pp. 2157-2166.

Yip, Paul S.F., Lee, Joseph and Cheung, Y.B., 2002. "The Influence of the Chinese Zodiac on Fertility in Hong Kong SAR”, Social Science \& Medicine, vol. 55, pp. 18031812

Zimmerman, Seth D., 2019. "Elite Colleges and Upward Mobility to Top Jobs and Top Incomes”, American Economic Review, vol. 109, pp. 1-47. 
Appendix Table A1

The Impact of Zodiacs on Marriages and Live Births in Chinese Provinces

\begin{tabular}{|c|c|c|c|c|}
\hline & $(1)$ & (2) & (3) & (4) \\
\hline & Marriages & Marriages & $\begin{array}{l}\text { Log (Live } \\
\text { Births) }\end{array}$ & $\begin{array}{l}\text { Log (Live } \\
\text { Births) }\end{array}$ \\
\hline Tiger year & & $\begin{array}{c}1.844^{* * *} \\
{[0.001]}\end{array}$ & & $\begin{array}{c}-0.005 \\
{[0.670]}\end{array}$ \\
\hline Rabbit year & & $\begin{array}{c}2.142 * * * \\
{[0.000]}\end{array}$ & & $\begin{array}{c}0.015 \\
{[0.172]}\end{array}$ \\
\hline Dragon year & $\begin{array}{c}0.655 \\
{[0.195]}\end{array}$ & $\begin{array}{l}0.957^{*} \\
{[0.089]}\end{array}$ & $\begin{array}{c}0.046 * * * \\
{[0.000]}\end{array}$ & $\begin{array}{c}0.050^{* * *} \\
{[0.000]}\end{array}$ \\
\hline $\begin{array}{l}\text { Province-Specific } \\
\text { Linear Trends }\end{array}$ & $\mathrm{Y}$ & $\mathrm{Y}$ & Y & $\mathrm{Y}$ \\
\hline $\begin{array}{l}\text { Province Fixed } \\
\text { Effects }\end{array}$ & $\mathrm{Y}$ & $\mathrm{Y}$ & $\mathrm{Y}$ & $\mathrm{Y}$ \\
\hline $\mathrm{N}$ & 971 & 971 & 319 & 319 \\
\hline
\end{tabular}

In columns 1 and 2 the outcome is the number of marriages approved by the government annually per 10,000 population. Data in columns 1 and 2 span the years 1979 to 2013 . The data used in regressions reported in columns 3 and 4 span the years 2003 to 2013. The mean value of log live births is 12.67. All regressions include provincial GDP. In column 3 and 4, the number of newly approved marriages are also included as a covariate. $P$-values are reported in the parentheses. Standard errors are obtained using the Wild-cluster bootstrap procedure. *significant at $10 \%$, ** significant at $5 \%, * * *$ significant at $1 \%$. 
Table A2

The Impact of Dragon Zodiac on Mid-Term Test Scores in Middle School CEPS Data (Using Adjusted Dragon Dummy)

\begin{tabular}{|c|c|c|c|}
\hline Variables & $\begin{array}{l}(1) \\
\text { Test Score in } \\
\text { Math }\end{array}$ & $\begin{array}{l}(2) \\
\text { Test Score in } \\
\text { Chinese }\end{array}$ & $\begin{array}{c}\text { (3) } \\
\text { Test Score in } \\
\text { English }\end{array}$ \\
\hline Dragon (Adjusted) & $\begin{array}{c}0.394 \\
(0.606)\end{array}$ & $\begin{array}{c}0.764 * * \\
(0.304)\end{array}$ & $\begin{array}{c}1.005 * * \\
(0.496)\end{array}$ \\
\hline Female & $\begin{array}{l}1.525 * * * \\
(0.489)\end{array}$ & $\begin{array}{l}6.817 * * * \\
(0.253)\end{array}$ & $\begin{array}{l}11.032 * * * \\
(0.458)\end{array}$ \\
\hline Age & $\begin{array}{l}-3.616 * * * \\
(0.425)\end{array}$ & $\begin{array}{l}-1.326 * * * \\
(0.198)\end{array}$ & $\begin{array}{l}-3.079 * * * \\
(0.352)\end{array}$ \\
\hline Single Child & $\begin{array}{c}0.402 \\
(0.538)\end{array}$ & $\begin{array}{l}-0.090 \\
(0.271)\end{array}$ & $\begin{array}{l}0.927 * * \\
(0.455)\end{array}$ \\
\hline Father Bachelor Degree or Above & $\begin{array}{l}4.681^{* * *} \\
(0.863)\end{array}$ & $\begin{array}{l}1.951 * * * \\
(0.409)\end{array}$ & $\begin{array}{l}4.131 * * * \\
(0.712)\end{array}$ \\
\hline Mother Bachelor Degree or Above & $\begin{array}{l}3.326 * * * \\
(0.758)\end{array}$ & $\begin{array}{c}1.076 * * * \\
(0.387)\end{array}$ & $\begin{array}{l}3.591 * * * \\
(0.621)\end{array}$ \\
\hline Father White Collar & $\begin{array}{c}0.526 \\
(0.647)\end{array}$ & $\begin{array}{c}0.478 \\
(0.317)\end{array}$ & $\begin{array}{c}0.460 \\
(0.563)\end{array}$ \\
\hline Mother White Collar & $\begin{array}{l}-0.128 \\
(0.680)\end{array}$ & $\begin{array}{c}0.497 \\
(0.360)\end{array}$ & $\begin{array}{c}0.644 \\
(0.651)\end{array}$ \\
\hline Family Has High Income & $\begin{array}{l}-1.950 * * \\
(0.881)\end{array}$ & $\begin{array}{l}-0.374 \\
(0.420)\end{array}$ & $\begin{array}{l}-1.251^{*} \\
(0.715)\end{array}$ \\
\hline $\begin{array}{l}\text { Mother Answers the Parents' } \\
\text { Survey }\end{array}$ & $\begin{array}{l}0.862 * * \\
(0.438)\end{array}$ & $\begin{array}{c}0.056 \\
(0.225)\end{array}$ & $\begin{array}{c}0.374 \\
(0.389)\end{array}$ \\
\hline $\begin{array}{l}\text { Average Mid-Term Exam Scores } \\
\text { Classroom Fixed Effects } \\
\mathrm{N}\end{array}$ & $\begin{array}{l}81.57 \\
Y \\
13,309\end{array}$ & $\begin{array}{c}85.41 \\
Y \\
13,309\end{array}$ & $\begin{array}{l}82.27 \\
Y \\
13,309\end{array}$ \\
\hline
\end{tabular}




\section{Table A3}

The Impact of Dragon Zodiac on Mid-Term Test Scores in the $8^{\text {th }}$ Grade Accounting for Parental Expectations in the $7^{\text {th }}$ Grade -- CEPS Data

\begin{tabular}{|c|c|c|c|}
\hline Variables & $\begin{array}{c}(1) \\
\text { Test Score in } \\
\text { Math }\end{array}$ & $\begin{array}{c}(2) \\
\text { Test Score } \\
\text { in Chinese }\end{array}$ & $\begin{array}{c}(3) \\
\text { Test Score in } \\
\text { English }\end{array}$ \\
\hline \multicolumn{4}{|c|}{ Panel A: Without Controlling for Parental Expectations } \\
\hline Dragon & $\begin{array}{c}0.697 \\
(0.760)\end{array}$ & $\begin{array}{l}0.979 * * \\
(0.399)\end{array}$ & $\begin{array}{l}1.232^{* *} \\
(0.609)\end{array}$ \\
\hline $\mathrm{N}$ & 7,089 & 7,089 & 7,085 \\
\hline \multicolumn{4}{|c|}{ Panel B: Controlling for Parental Expectations } \\
\hline Dragon & $\begin{array}{c}-0.211 \\
(0.720)\end{array}$ & $\begin{array}{c}0.557 \\
(0.378)\end{array}$ & $\begin{array}{c}0.506 \\
(0.581)\end{array}$ \\
\hline $\mathrm{N}$ & 7,089 & 7,089 & 7,085 \\
\hline
\end{tabular}


Table A4

Smoothness of the Covariates (CGSS)

\begin{tabular}{|c|c|c|c|c|}
\hline Variables & $\begin{array}{c}\text { (1) } \\
\text { Female }\end{array}$ & $\begin{array}{c}(2) \\
\text { Minority }\end{array}$ & $\begin{array}{c}\text { (3) } \\
\text { Father Bachelor } \\
\text { Degree or Above }\end{array}$ & $\begin{array}{c}\text { (4) } \\
\text { Mother Bachelor } \\
\text { Degree or Above }\end{array}$ \\
\hline Dragon & $\begin{array}{l}-0.05 \\
(0.07)\end{array}$ & $\begin{array}{l}-0.02 \\
(0.03)\end{array}$ & $\begin{array}{c}-0.02 \\
(0.03)\end{array}$ & $\begin{array}{c}-0.01 \\
(0.02)\end{array}$ \\
\hline $\begin{array}{l}p \text {-value } \\
\mathrm{N}\end{array}$ & $\begin{array}{l}0.458 \\
1,827\end{array}$ & $\begin{array}{l}0.457 \\
1,827\end{array}$ & $\begin{array}{l}0.395 \\
1,827\end{array}$ & $\begin{array}{l}0.780 \\
1,827\end{array}$ \\
\hline
\end{tabular}


Table A5

The Dragon Effect on the Propensity of Having a Bachelor's Degree or Higher Regression Discontinuity Estimates

(CGSS Data)

(1)

\begin{tabular}{lcc} 
Variables & Bachelor or Higher Degree & Bachelor or Higher Degree \\
\hline Panel A: & $1^{\text {st }}$ order polynomial & $2^{\text {nd }}$ order polynomial \\
\hline Dragon & $0.06^{* *}$ & $0.08^{* *}$ \\
& $(0.03)$ & $(0.04)$ \\
& & \\
$p$-value & 0.031 & 0.044 \\
$\mathrm{~N}$ & 5,696 & 5,696 \\
\hline
\end{tabular}

\begin{tabular}{lcccc} 
Panel B: & BW=1 CCFT & BW=0.85 CCFT & BW=1.25 CCFT & BW=1.5 CCFT \\
\hline Dragon & $0.07^{*}$ & $0.08^{*}$ & $0.08^{* *}$ & $0.07^{* *}$ \\
& $(0.04)$ & $(0.04)$ & $(0.04)$ & $(0.03)$ \\
& & & & \\
$p$-value & 0.063 & 0.075 & 0.036 & 0.032 \\
$\mathrm{~N}$ & 2,990 & 2,350 & 3,969 & 4,955 \\
\hline
\end{tabular}

Control variables include individuals' age, gender, ethnicity, health status, parents' educational level and employment status, wave fixed effects and province fixed effects. Panel A reports the parametric RD estimates. The sample includes all individuals born between 1987 and 1989, with a Dragon cohort of 1988. Panel B reports the RD estimates obtained from estimating local linear regressions with a triangular kernel. In Panel B, the optimal bandwidths were selected for each side of the cutoff separately using the MSEbandwidth introduced by Calonico et al. $(2017,2018)$ using a triangular kernel. The optimal bandwidths are 569 and 162 for the left and right sides of the cutoff, respectively, (represented by the acronym CCFT). Standard errors are clustered at the running variable level and reported in the parentheses. *significant at $10 \%$, ** significant at $5 \%$, *** significant at $1 \%$ 


\section{Appendix Table A6 \\ Analyses of Middle School Students-Grade 7 Students Only \\ (CEPS Data)}

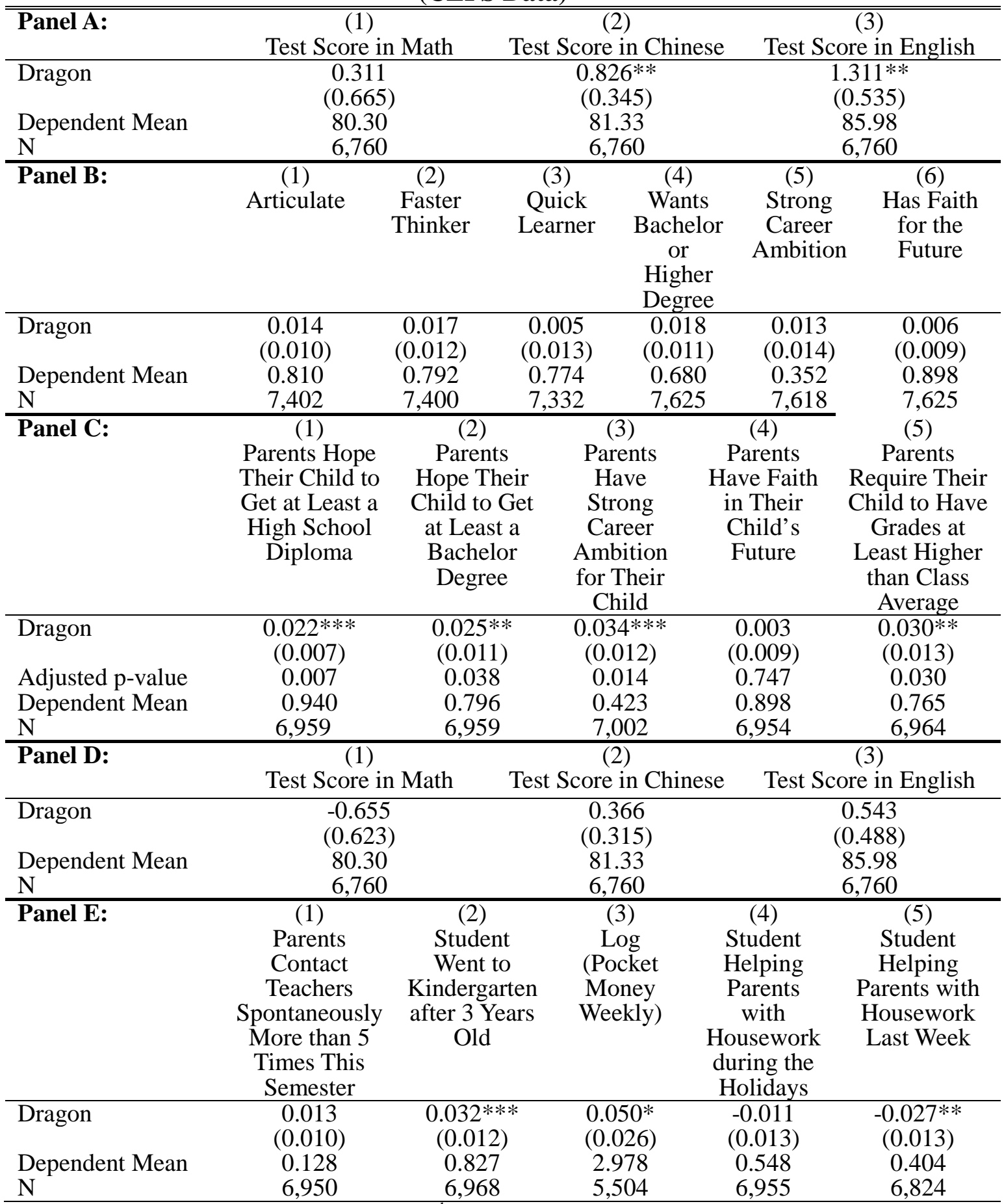

The working samples are restricted to the $7^{\text {th }}$ grade students. A full set of covariates are controlled for in all regressions. Adjusted p-values for multiple-hypothesis testing in Panel C use the Simes adjustment. Standard errors are clustered at classroom level and reported in the parentheses. *significant at $10 \%$, ** significant at $5 \%$, *** significant at $1 \%$. 


\section{Appendix Table A7 \\ Test Scores of Tigers and Rabbits \\ Grade 9 Students Only (CEPS Data)}

\begin{tabular}{|c|c|c|c|}
\hline Variables & $\begin{array}{c}(1) \\
\text { Test Score in } \\
\text { Math }\end{array}$ & $\begin{array}{c}(2) \\
\text { Test Score in } \\
\text { Chinese }\end{array}$ & $\begin{array}{c}(3) \\
\text { Test Score in } \\
\text { English }\end{array}$ \\
\hline Tiger & $\begin{array}{l}-0.233 \\
(0.718)\end{array}$ & $\begin{array}{c}0.517 \\
(0.353)\end{array}$ & $\begin{array}{c}0.394 \\
(0.636)\end{array}$ \\
\hline Female & $\begin{array}{l}1.446 * \\
(0.745)\end{array}$ & $\begin{array}{l}7.032 * * * \\
(0.394)\end{array}$ & $\begin{array}{l}11.871 * * * \\
(0.701)\end{array}$ \\
\hline Age & $\begin{array}{l}-3.095 * * * \\
(0.616)\end{array}$ & $\begin{array}{l}-1.056 * * * \\
(0.288)\end{array}$ & $\begin{array}{l}-2.325 * * * \\
(0.527)\end{array}$ \\
\hline Single Child & $\begin{array}{c}0.214 \\
(0.861)\end{array}$ & $\begin{array}{l}-0.572 \\
(0.421)\end{array}$ & $\begin{array}{c}0.254 \\
(0.717)\end{array}$ \\
\hline Father Bachelor Degree or Above & $\begin{array}{c}6.285 * * * \\
(1.471)\end{array}$ & $\begin{array}{l}3.509 * * * \\
(0.650)\end{array}$ & $\begin{array}{l}5.959 * * * \\
(1.232)\end{array}$ \\
\hline Mother Bachelor Degree or Above & $\begin{array}{l}4.088 * * * \\
(1.236)\end{array}$ & $\begin{array}{c}0.930 \\
(0.621)\end{array}$ & $\begin{array}{l}4.268 * * * \\
(1.106)\end{array}$ \\
\hline Father White Collar & $\begin{array}{l}2.241 * * \\
(1.095)\end{array}$ & $\begin{array}{c}1.423 * * * \\
(0.510)\end{array}$ & $\begin{array}{l}1.924^{*} \\
(0.990)\end{array}$ \\
\hline Mother White Collar & $\begin{array}{l}0.406 \\
(1.168)\end{array}$ & $\begin{array}{l}1.172 * \\
(0.599)\end{array}$ & $\begin{array}{c}1.832 \\
(1.224)\end{array}$ \\
\hline Family Has High Income & $\begin{array}{l}-1.164 \\
(1.338)\end{array}$ & $\begin{array}{l}-0.423 \\
(0.670)\end{array}$ & $\begin{array}{l}-1.196 \\
(1.152)\end{array}$ \\
\hline $\begin{array}{l}\text { Mother Answers the Parents' } \\
\text { Survey }\end{array}$ & $(0.683)$ & $(0.357)$ & $(0.640)$ \\
\hline $\begin{array}{l}\text { Classroom Fixed Effects } \\
\mathrm{N}\end{array}$ & $\begin{array}{c}\mathrm{Y} \\
6,549\end{array}$ & $\begin{array}{c}\mathrm{Y} \\
6,549\end{array}$ & $\begin{array}{c}Y \\
6,549\end{array}$ \\
\hline
\end{tabular}

Dependent variables are scores in Mathematics, Chinese and English on mid-term tests. Students' type of hukou (certificate of residency) are controlled for. Standard errors are clustered at classroom level and reported in the parentheses. *significant at $10 \%$, ** significant at 5\%, $* * *$ significant at $1 \%$. 
Table A8

Parents' Expectations of Children (Tigers and Rabbits) Grade 9 Students Only (CEPS Data)

\begin{tabular}{|c|c|c|c|c|c|}
\hline Variables & $\begin{array}{c}\text { (1) } \\
\text { Parents Hope Their } \\
\text { Child to Get at Least a } \\
\text { High School Diploma }\end{array}$ & $\begin{array}{c}\text { (2) } \\
\text { Parents Hope Their } \\
\text { Child to Get at Least } \\
\text { a Bachelor Degree }\end{array}$ & $\begin{array}{c}\text { (3) } \\
\text { Parents Have } \\
\text { Strong Career } \\
\text { Ambition for } \\
\text { Their Child }\end{array}$ & $\begin{array}{l}\text { (4) } \\
\text { Parents Have } \\
\text { Faith in Their } \\
\text { Child's Future }\end{array}$ & $\begin{array}{c}(5) \\
\text { Parents Require } \\
\text { Their Child to at } \\
\text { Least Have Grades } \\
\text { Higher than } \\
\text { Average }\end{array}$ \\
\hline Parent of a Dragon Child & $\begin{array}{c}0.000 \\
(0.007)\end{array}$ & $\begin{array}{c}-0.011 \\
(0.013)\end{array}$ & $\begin{array}{c}0.004 \\
(0.013)\end{array}$ & $\begin{array}{l}-0.010 \\
(0.009)\end{array}$ & $\begin{array}{c}0.001 \\
(0.012)\end{array}$ \\
\hline Female & $\begin{array}{c}0.022^{* * *} \\
(0.007)\end{array}$ & $\begin{array}{c}0.036 * * * \\
(0.011)\end{array}$ & $\begin{array}{c}-0.167 * * * \\
(0.012)\end{array}$ & $\begin{array}{c}0.021^{* *} \\
(0.010)\end{array}$ & $\begin{array}{c}0.028 * * \\
(0.012)\end{array}$ \\
\hline Age & $\begin{array}{c}-0.016 * * * \\
(0.006)\end{array}$ & $\begin{array}{c}-0.042 * * * \\
(0.010)\end{array}$ & $\begin{array}{c}-0.020^{* *} \\
(0.010)\end{array}$ & $\begin{array}{c}-0.021 * * * \\
(0.007)\end{array}$ & $\begin{array}{c}-0.033 * * * \\
(0.009)\end{array}$ \\
\hline Single Child & $\begin{array}{c}0.006 \\
(0.008)\end{array}$ & $\begin{array}{c}0.017 \\
(0.013)\end{array}$ & $\begin{array}{l}-0.015 \\
(0.016)\end{array}$ & $\begin{array}{l}-0.001 \\
(0.010)\end{array}$ & $\begin{array}{l}-0.003 \\
(0.015)\end{array}$ \\
\hline Mother Answers the Parents' Survey & $\begin{array}{c}0.006 \\
(0.007)\end{array}$ & $\begin{array}{c}0.028 * * \\
(0.012)\end{array}$ & $\begin{array}{c}-0.034^{* * *} \\
(0.013)\end{array}$ & $\begin{array}{l}-0.011 \\
(0.009)\end{array}$ & $\begin{array}{c}0.000 \\
(0.012)\end{array}$ \\
\hline Father Bachelor Degree or Above & $\begin{array}{c}0.022 * * * \\
(0.008)\end{array}$ & $\begin{array}{c}0.087 * * * \\
(0.016)\end{array}$ & $\begin{array}{l}-0.011 \\
(0.027)\end{array}$ & $\begin{array}{c}0.004 \\
(0.014)\end{array}$ & $\begin{array}{c}0.100 * * * \\
(0.020)\end{array}$ \\
\hline Mother Bachelor Degree or Above & $\begin{array}{l}-0.006 \\
(0.009)\end{array}$ & $\begin{array}{l}-0.005 \\
(0.016)\end{array}$ & $\begin{array}{l}-0.038 \\
(0.027)\end{array}$ & $\begin{array}{c}0.013 \\
(0.015)\end{array}$ & $\begin{array}{c}0.033 \\
(0.026)\end{array}$ \\
\hline Father White Collar & $\begin{array}{c}0.007 \\
(0.008)\end{array}$ & $\begin{array}{l}0.026 * \\
(0.015)\end{array}$ & $\begin{array}{c}0.102^{* * *} \\
(0.020)\end{array}$ & $\begin{array}{c}0.014 \\
(0.012)\end{array}$ & $\begin{array}{l}0.037^{*} \\
(0.019)\end{array}$ \\
\hline Mother White Collar & $\begin{array}{l}0.017^{* *} \\
(0.008)\end{array}$ & $\begin{array}{c}0.060 * * * \\
(0.014)\end{array}$ & $\begin{array}{c}0.021 \\
(0.027)\end{array}$ & $\begin{array}{c}0.019 \\
(0.015)\end{array}$ & $\begin{array}{c}0.032 \\
(0.020)\end{array}$ \\
\hline Family Has High Income & $\begin{array}{l}-0.003 \\
(0.011)\end{array}$ & $\begin{array}{c}0.002 \\
(0.020)\end{array}$ & $\begin{array}{l}0.053^{*} \\
(0.027)\end{array}$ & $\begin{array}{c}0.056 * * * \\
(0.012)\end{array}$ & $\begin{array}{l}-0.046 * \\
(0.024)\end{array}$ \\
\hline $\begin{array}{l}\text { Classroom Fixed Effects } \\
\mathrm{N}\end{array}$ & $\begin{array}{c}\mathrm{Y} \\
6,805 \\
\end{array}$ & $\begin{array}{c}\mathrm{Y} \\
6,805 \\
\end{array}$ & $\begin{array}{c}\mathrm{Y} \\
6,792 \\
\end{array}$ & $\begin{array}{c}\mathrm{Y} \\
6,793 \\
\end{array}$ & $\begin{array}{c}\mathrm{Y} \\
6,805 \\
\end{array}$ \\
\hline
\end{tabular}


